\title{
20. YÜZYILI KARŞILARKEN OSMANLI DEVLETI’'NDE YABANCI OKULLARIN DENETIMİ SORUNU VE PROTESTAN OKULLARI ÖRNEĞİ
}

\section{Halil ÖZEÇOĞLU ${ }^{1}$}

\section{ÖZET}

Yabancı okullara dair çeşitli çalışmalar yapılmış olmasına rağmen, bu okulların denetimlerine dair literatürde görünen boşluğu, Protestan okullarını da ele alarak Cumhurbaşkanlığı Osmanlı Arşivi belgeleri temelinde değerlendirmek, araştırmanın ana eksenini oluşturmaktadır. Çalışmamızda yayımladığımız Mekatib-i Gayr-i Müslime ve Ecnebiye Müfettişliği Nizamnamesi'nde bu okulların teftişi, öğretmenleri, öğrencileri ve kitapları ayrıntılı bir şekilde kaleme alınmıştır. Osmanlı Devleti, Müslüman okullarını yabancı okullara karşı üstün hale getirmeye çalışmakta, padişah, İstanbul ve Osmanlı bürokratları yabancı okulların ve Protestan okullarının denetimi konusunda fikir birliği içerisinde gözükmektedir. Bu okulların ruhsata bağlanıp, teftiş altında bulundurulmaları, devletin yabancı okullara ilişkin eğitim politikasında temel bir gayret olarak ortaya çıkmaktadır. Ancak padişah iradesine rağmen yabancı okulların ruhsatsız olarak açılması ve Müslüman çocukların, yine padişah iradesiyle yasaklanmasına rağmen, bu okullara devam etmeleri, Osmanlı Devleti'nin eğitim politikaları açısından ilginç bir duruma projeksiyon tutmaktadır. Osmanlı memurları teftiş konusunda sefaret ve konsolosluk engeliyle karşılaşmakta, "Düvel-i Muazzama"nın nüfuz alan hinterlandının merkezinde birer eğitim istasyonu olan bu okulların kadroları ise vatandaşı oldukları ülkelerin koruma şemsiyesi altında rahatça hareket edebilmektedir.

Anahtar Kelimeler: Osmanlı, Eğitim, Yabancı Okullar, Protestan Okulları, Teftiş.

\section{WHILE WELCOMING THE 20TH CENTURY, THE PROBLEM OF INSPECTION OF THE FOREIGNERS' SCHOOLS OF THE OTTOMAN EMPIRE AND A SAMPLE OF PROTESTANTS' SCHOOLS}

\begin{abstract}
Although various studies have been made relevant to the foreigners' schools, evaluating the lack of the inspection of these schools by dealing with the Protestant schools and on the basis of the Presidency Ottoman Archive documents forms are the main aim of this study. In the Regulations of the Inspectorship of the Schools of Non-Muslim and Foreigners brought out in this study, teachers, pupils, course books and the inspection of these schools have been written down in detail. The Ottoman Empire tried to make the Muslims' schools superior to the foreigners' schools. The Sultan, Government of İstanbul and the Ottoman bureaucrats seemed that they all had the same consensus about the inspection of the Protestants' and foreigners' schools. Making these schools get the licence and be under inspection occur as a basic effort of the government's educational policy about foreigners' schools. However, opening up the foreigners' schools without any licence and the case that Muslim children attend those schools despite the Sultan's prohibition point to an interesting fact in terms of educational policies of the Ottoman Empire. While Ottoman officers were encountering embassy and consular obstacles
\end{abstract}

${ }^{1}$ Dr., Milli Eğitim Bakanlığı, Mehmet Akif Ersoy Sosyal Bilimler Lisesi, e-posta: halilozecoglu @ windowslive.com 
about the inspection, the staff of those foreigners' schools were working in an untroubled way under the protection of the country they were the citizens of. Those foreigners' schools can be referred to as education stations in the central area of influence of the great states.

Key Words: Ottoman, Education, Foreigners' Schools, Protestants' Schools, Inspection.

\section{Giriş}

19. yüzyılın sonları ve 20. yüzyılın başlarında Osmanlı eğitim siyasası dünyanın değişen koşullarında daha çok tehdit altında hissedilen bir sosyal nizamın ideolojik meşruiyetini pekiştirmeyi istemekteydi. Diğer imparatorluklarda olduğu gibi, Osmanlı İmparatorluğu'nda da eğitim sistemindeki temel sorun, halklarının aidiyet duygusunu güçlendirmekti. Din ve milliyetin birbirinin yerine kullanılabildiği Osmanlı İmparatorluğu'nda, modern dünya ile entegre halde merkezin değer sisteminin desteğinde uyrukların yavaş yavaş modernleştirilmesi temel bir gayretti. Fakat bu dönemde Osmanlı yöneticileri kendi değerlerini öğretme mücadelesini verirken, İttihat ve Terakki'den başka, yabancı misyonerlerin de muhalefetiyle karşı karşıya kalacaklardı (Deringil, 2002: 114-117). Zaten Müslüman ve gayrimüslimler arasındaki sosyo-ekonomik fark, Müslümanların eğitimlerinin geliştirilmesi gereğini göstermekteydi. Kendi okullarını finanse etmede fazla başarı sağlayamayan Müslüman tebaanın eğitimi devlete kalmaktaydı. Vilayetlerdeki yabancı misyoner okulları da devletin harekete geçmesinde etkiliydi; çünkü yabancı dil öğrenememe kaygısı, özellikle ticari hareketliliğin yaşandığı periferide, Müslüman halkın çocuklarını yabancı okullara gönderme yönelimini ortaya çıkarmaktaydı. Yabancı okulların yeterince teftiş edilemediğini düşünen Osmanlı yöneticileri, denetimleri altında bulunmayan bu kurumlara çocukların teslim edilmesinin ne kadar zararlı olduğunu düşünmekteydiler (Uyanık, 2017: 1-2).

\section{Kamusal Metinlerde Yabancı Mektepler}

1869 tarihli Maarif-i Umumiye Nizamnamesi'nin 129.maddesindeki "Mekatib-i hususiye, bazı mahallerde cemaatler tarafindan veya gerek tebaa-i Devlet-i Aliyye ve gerek tebaa-i ecnebiyeden olan efrad ve eşhasdan biri canibinden ücretli veya ücretsiz olarak ihdas ve tesis olunan mekteplerdir" (YEE 112/6), ifadesi Osmanlı Devleti'nde yabanc1 mekteplerin özel okullar kategorisinde değerlendirildiğini göstermektedir. Yine bu nizamnamenin aynı maddesine göre, yabancı mekteplerin de dahil olduğu özel okulların açılması için ise öğretmenlerinin elinde Maarif Nezareti veya mahalli maarif idaresi tarafindan verilmiş diplomanın olması, mekteplerde adaba ve politikaya aykırı ders okutturulmaması için talim olunacak derslerin cetvelinin ve kitapların, Maarif Nezareti'nden veya mahalli maarif idaresinden onaylı olmak üzere resmi ruhsatın da taşrada vilayet maarif idaresiyle vilayet valisi, İstanbul'da ise Maarif Nezareti tarafindan verilmesi gerekmektedir (YEE 112/6).

1876 tarihli Kanun-1 Esasi’nin 15. maddesinde öğretimin serbest olduğu ve belirli olan kanuna uymak koşuluyla, her Osmanlının genel ve özel öğretime izinli olduğu ifade edilirken, 16. maddede bütün mekteplerin devletin denetimi altında olduğu yazmaktadır (Kili ve 
Gözübüyük, 2000: 44). Burada, öğretimin serbestliğiyle beraber öğretim izni konusunda yabancılardan bahsedilmemekte fakat denetim konusuna tüm okullar dahil edilmektedir.

6 Eylül 1888 tarihli Mekatib-i Gayr-i Müslime ve Ecnebiye Müfettişliği Nizamnamesi ${ }^{2}$ (Y PRK MF 1/63), Osmanlı Devleti'nde yabancı okulların nasıl olması gerektiği sorusunu en net biçimde yanıtlayan hukuki metindir. Bu metnin maddeleri aşağıda verilmiştir.

1. Madde: İstanbul Mekatib-i Gayr-i Müslime ve Ecnebiye Müfettişliği, Maarif Nezareti'ne bağlidır.

2. Madde: Müfettiş, gayrimüslim ve ecnebi mekteplerini imkân derecesinde teftiş ederek, bunların iç durumlarını araştırıp, mükemmel bir genel defterini düzenleyerek, bunu Maarif Nezareti'ne takdim edecektir.

3. Madde: Gayrimüslim ve ecnebi mekteplerinde okutturulan kitapların içeriğinde devletin dini ve saltanatın menfaatleri aleyhinde zararlı ibareler bulunup bulunmadığını bilmek ve ona göre zararları ortaya çıkanların mekteplere sokulmamasına ve öğrencilerin ellerinde bulundurulmamasına nezaret etmek için, öncelikle her sene, mekteplerin tatillerinin bittiği ve açılacakları zamanda, her mektepte okutturulacak kitapların değiştirilmemiş olsalar bile, Encümen-i Teftiş ve Muayene'ye verilip, tetkik ettirilmesi ve program onaylattırıldıktan sonra mekteplerde öğretimine izin verilmesi gerekmektedir.

4. Madde: Hangi din, mezhep, millet ve tebaadan olursa olsun, gayrimüslim ve ecnebi mekteplerinin öğretim işleri Maarif Nezareti’nin kanunlarına tabi olacaktır.

5. Madde: Müfettişin vazifesi dahilinde gerçekleştireceği incelemeler için gayrimüslim ve ecnebi mekteplerinden her birisine başvuruldukça, bu konuda sorulan sorulara mekteplerin müdür ve reisleri tarafindan gerekli cevaplar verilecektir. Mekteplerin gerek dershane ve kitapları, gerek sair yerleri muayene ve teftiş edilmek gerekirse, müfettişe açılacaktır. Kısacası, teftişin her yönüne uygunluk ve kolaylık gösterilerek ecnebilerin mensup oldukları sefaretlere güvenilerek ya da onlardan alacakları izne bağlı olarak teftiş durumu engellenmeyecektir.

6. Madde: Gayrimüslim ve ecnebi mektepleri iki kısım olacaktır. Birincisi daha önce açılıp aleni olarak öğretim işleri yapılan, ikincisi bundan sonra resmi ruhsat ile açılması istenecek olan mekteplerdir. $\mathrm{Bu}$ mekteplerden daha önce ruhsat verilmiş olanların ruhsatnameleri müfettiş vasıtasıyla Meclis-i Maarif'e verilerek, tetkik ve tasdik ettirilecektir. Ruhsatnamesi olmayanların da usulünce ruhsatname almak için bu nizamnamenin neşrinden altı aya kadar olan sürede mektep sahipleri tarafından Maarif Nezareti'ne dilekçe ile başvuruları mecbur olacaktır. Belirtilen tarihten sonra, böyle bir başvuru yapılmadığı ve yine mektepte öğretime devam edilmekte olunduğu, müfettiş vasıtasıyla ortaya çıkarılırsa, kanuni muameleleri yapılıncaya kadar, bu mektepler kesinlikle kapatılacaktır.

7. Madde: Gayrimüslim olan, Osmanlı ve ecnebi tebaası tarafından İstanbul'da milli ve özel okul açılması istenildiği zaman, önce Maarif Nezareti'ne dilekçe verilecek ve açılacak mektep yeni olarak mı inşa edilecektir? Yoksa var olan ve mamur bir hane daimi veya geçici

\footnotetext{
${ }^{2}$ Şimdiye kadar herhangi bir çalışmada yayımlandığını tespit edemediğimiz bu nizamnamede gayrimüslim ve ecnebi mektepleri genelde beraber kaleme alınmıştır. Konu gereği, burada, nizamnamede bahsi geçen ecnebi mektepleri değerlendirilecektir.
} 
olarak mektep haline mi dönüştürülecektir? Burası ve Maarif Nizamnamesi'nin 129. maddesinde belirli olan ruhsat şartlarından başka, kurulacak mektebin mahalli, yatılı veya gündüzlü olacağı ve öğrencilere giydirilecek elbisenin çeşidi ve şekli ve tahsil seviyeleri esasına göre mektebin dereceleri ve okutturulacak kitapların programı beyan edilecektir.

Mektepte ecnebi ve tebaadan kaç öğretmen bulundurulacak ise bu öğretmenler, tabiyetlerini ve sanatlarını içeren ve mensup oldukları dairelerden onaylı özgeçmişlerini vermeye mecbur olacaklardır. Verilen dilekçe Maarif Nezareti'nce dikkate alınıp; yer, şekil ve siyasi olarak bu mektebin açılmasında mahzur olmadığı resmen meydana çıkarılarak ve gerekli muameleler yapılarak padişah iradesi için hükümete arz edilecek ve nezaretin izni dahilinde olanlar için re'sen ruhsat verilip, müfettiş vasıtasıyla müdür ve kuruculara tebliğ edilecektir.

8. Madde: Gerek önceden açılmış, gerekse padişah iradesi ile yeni olarak açılacak ecnebi ve gayrimüslim mekteplerinin kurucuları hangi mezhepten ise o mezhebe mensup gayrimüslim Osmanlı tebaası mektebe her yaşta kabul edilebilecektir. Ancak diğer Hıristiyan ve Musevi mekteplerinde bulunan erkek ve kız çocukları, kendi milletlerine mahsus ilk derece mekteplerinde okuyup, usul ve dini vazifelerini öğrenerek ruhani reislerinden diploma almadıkça ve ayırt etme yaşına gelmedikçe, diğer mezhep sınıflarında bulunan gayrimüslim ve ecnebi mekteplerine kabul edilmeyecektir.

9. Madde: Müslüman erkek ve kız çocuklarının hangi yaşta bulunursa bulunsun ecnebi mekteplerine alınmaları yasaktır. Yasağa aykırı olarak bu mekteplere kabul edilmiş olanlar, velilerine ve velileri olmadığı takdirde diğer mahalle yerleştirilmek üzere zaptiyeye teslim edilecektir.

10. Madde: Yabancı mekteplerinde Osmanlı tebaasından olan öğrencilere Türkçe ve gerçek anlamıyla Osmanlı Tarihi öğretimi mecbur olacaktır.

11. Madde: Gayrimüslim ve yabancı mekteplerinde diyanetle ilgili olarak okutturulacak dersler mektebin ilgili olduğu mezhebe dair olacak, farklı mezhepte bulunan gayrimüslim öğrenciler o derslerde bulunmayacaktır.

12. Madde: Gayrimüslim ve ecnebi mekteplerinde mezheple ilgili okunacak dersler, o mektebin ruhani reisleri ve fenle ilgili olanlar da Maarif Nezareti tarafindan onaylanmadıkça kabul edilmeyecektir.

13. Madde: Gayrimüslim ve ecnebi mekteplerinde nizama aykırı bir durum ve hareket görüldüğ̈ zaman bu durumun düzeltilmesi, müfettiş vasitasıyla resmen mektep yönetimine yazılı olarak ihtar olunacak ve söz dinlenmediği takdirde mektep, hükümet marifetiyle kapatılacaktır.

14. Madde: Gayrimüslim ve ecnebi mekteplerinde İslam dini, hukuk-1 mukaddese, padişah ve Osmanlı Devleti'nin aleyhinde ve ecnebi politikasını destekleme yolunda zararlı kitapları okutan ve gizlice mektebe sokan ve öğrencilerin ellerine vererek, bunları kullandıran ve öğrencilere sözlü olarak fesat fikirler telkin eden müdür ve muallimler rütbelerine göre mektepten atılacaklar ve haklarında ceza kanunu uygulanacaktır. 
15. Madde: Gayrimüslim ve ecnebi mekteplerinde bugün mevcut olan öğrenciler, müfettiş vasıtasıyla deftere kayıt edilerek, bunlardan 8. madde hükümlerine aykırı olarak daha önceden alınıp, kendilerinde ahlakça emniyet ve bilimsel ilerlemelerde gayretleri görülmüş olan Osmanlı tebaası gayrimüslim çocuklarının öğretim sürelerinin sonuna kadar mektepte kalmaları Osmanlı hükümetinin iznine bağlı olmak üzere, bundan sonra bu mekteplere alınacak öğrenciler tamamıyla bu nizamname hükümlerine uygun olarak kabul edilecektir.

16. Madde: Gayrimüslim Osmanlı tebaasından gayrimüslim ve ecnebi mekteplerinde bulunmuş ve bulunacak olan erkek öğrenciler genel olarak fes giyecek, müdür ve öğretmenlerine karşı tören adabıyla milli adetlerini yerine getirme zorunluluklarına mektep yönetimince asla halel getirilmeyecektir.

17. Madde: Padişah iradesi olmadan hiçbir ecnebi mektebi yeni olarak açılamayacağı gibi, resmi ruhsatı alınarak eskiden beri bir vaka olarak açılmış olan ecnebi milli ve özel mektepleri bu nizamname hükmünce gerekli şartlara uygun muamele edilerek, hüviyetini ispat ile altı ay zarfında ruhsatı içeren padişah fermanı verilmedikçe tatil edilecektir.

18. Madde: Gerek burada basılan ve gerekse Avrupa'dan basılı olarak gelmiş bulunan kitaplardan gayrimüslim ve ecnebi mekteplerinde okutturulanlar, gerçi Encümen-i Teftiş ve Muayene'ye tasdik ettirildikten sonra öğretimine izin veriliyorsa da, bunların haricinde ecnebi mektepleri adına İstanbul'a gelen ve mekteplerin kütüphanelerinde bulundurulan kitaplar da çoğunlukla şer'an ve siyaseten zararlı kitaplar bulunageldiğinden ders kitaplarından başka ecnebi mektepleri adına ne kadar kitap gelirse, Rüsumat Emaneti'nden Maarif Nezareti'ne gönderilerek müfettiş vasıtasıyla Encümen'de muayene ve teftiş ettirilerek ve içeriğinin zararsız olduğu tasdik ettirilmedikçe mektebe verilmeyip, Maarif'te saklanacaktır.

19. Madde: Gayrimüslim ve ecnebi mekteplerinden her birisinin dış kapısının üzerinde o mektebin çeşidi, yani milli veya özel olduğu ve kurucusunun ismi ve mektebin hangi millete mensup olduğu kalın ve okunaklı yazı ile Türkçe ve o milletin alfabesi ile yazılı birer levha asilacaktır (Y PRK MF 1/63).

Anlaşıldığı üzere, İstanbul Mekatib-i Gayr-i Müslime ve Ecnebiye Müfettişliği, Maarif Nezareti'ne bağlı olacak, müfettiş ecnebi mekteplerini, imkân dahilinde denetleyecek, ecnebi mekteplerindeki kitaplar İslam'a ve saltanatın menfaatlerine aykırı ibarelere sahip olmayacak, bunun için Encümen-i Teftiş ve Muayene'nin onayı istenecek, mekteplerdeki öğretimde Maarif Nezareti'nin kanunları geçerli olacaktır.

Müfettişin vazifesi dahilinde yapacağı incelemelerde soruları cevaplanacak, müfettişe kolaylık gösterilecek, sefaretlerin desteği ile teftiş engellenmeyecektir. Ruhsatnamesi olmayan mektepler kapatılacaktır.

Nizamnamenin 7. maddesine göre, gayrimüslim Osmanlı tebaası tarafından İstanbul'da milli ve özel okul açılmak istenirse Maarif Nezareti'ne dilekçe verilecek, okulun yeni olarak mı dönüştürülerek mi açılacağı belirtilecek, Maarif-i Umumiye Nizamnamesi'nin 129. maddesinden başka, mektebin yatılı veya gündüzlü olmasından öğrencilere giydirilecek elbisenin çeşidine, çalıştırılacak öğretmenlerin özgeçmişlerine kadar, okulun tüm özellikleri bildirilerek ve okulun açılmasında herhangi bir sorun yoksa durum, padişah iradesi için 
hükümete arz edilecektir. MaarifNezareti'nin izni dahilinde olanlar içinse, re'sen ruhsat verilecektir. Yani 1888 yll itibariyle İstanbul için ruhsat verme, birinci olarak padişah iradesi, ikinci olarak da Eğitim Bakanlığı'nın izni dahilinde olanlar için re'sen olmak üzere iki şekildedir.

Nizamnamenin 17. maddesi de açılacak yabancı okulların izin şartını vermektedir. Şöyle ki; yeni açılacak olan yabancı okullar, padişah iradesini almak zorundadır. Ruhsatlarını daha önceden almış olanlar ise bu nizamnamenin şartlarına uygunluklarını ispatlayıp, altı ay içinde padişah fermanını almadıkça tatil edilecektir. Görüldüğü üzere, 7. maddede İstanbul için açılacaklarda padişah iradesi veya Maarif Nezareti'nin izni dahilinde olanlar için re'sen izin ifade edilmektedir. O zaman 17. maddedeki padişah izninin gerekliliği ifadesini, İstanbul dışındaki imparatorluk toprakları için düşünmek yanlış bir yaklaşım olmayacaktır. Sonuçta hem İstanbul, hem taşra için padişah izni gereklidir. Fakat sadece İstanbul'da Maarif Nezareti'nin izni dahilinde olanlar için re'sen ruhsat verme ibaresi vardır.

Mektebin kurucusunun mezhebinden olan gayrimüslim Osmanlı tebaası, mektebe, yaşına bakılmaksızın kabul edilecektir. Fakat diğer Hıristiyan ve Musevi mekteplerindeki çocuklar, kendi milletlerinin temel eğitimini alıp, usul ve dini görevlerini öğrenip, ruhani reislerinden diploma alıp, ayırt etme yaşına geldikleri takdirde diğer mezhep sınıflarındaki ecnebi mekteplerine kabul edilecektir. Fakat bu hükme aykırı olarak önceden kayıt edilenler varsa, bunlardan ahlaki ve bilimsel olarak uygun görülen Osmanlı tebaası gayrimüslim çocukları, hükümetin izni ile öğretim sürelerinin bitmesine kadar mektepte kalabilecek, bundan sonra alınacaklar ise bu nizamnameye göre kayıt edilecektir.

Müslüman çocuklarının yabancı mekteplere alınması yasaktır. Bu mekteplerdeki Müslüman çocukları bu okullardan alınacak, velilerine teslim edilecek, velileri yoksa zaptiyeye teslim edileceklerdir.

Yabancı okullarındaki Osmanlı tebaası, Türkçe ve Osmanlı Tarihi'ni zorunlu olarak okuyacaktır. Yabanc1 okullarındaki dinle ilgili dersler ise mektebin ilgili olduğu mezhebe dair olacaktır. Diğer mezhepten olan gayrimüslim öğrenciler, o derslere girmeyecektir. Ayrıca mezheple ilgili dersleri, o mezhebin ruhani reisleri, fenle ilgili olanları da Maarif Nezareti onaylayacaktır.

Ecnebi mekteplerinde kanuna aykırı bir durum ortaya çıkarsa ve uyarıya rağmen düzeltilmezse mektep kapatılacaktır. Ecnebi mekteplerinde İslam dini, Osmanlı Devleti, padişah ve hukuk-1 mukaddese aleyhinde ve yabanc1 politikaları lehinde kitaplar okutturan, bu kitapları mektebe sokup öğrencilere veren veya sözlü olarak öğrencilere fesat fikirler ima eden müdür ve öğretmenler mektepten atılacak ve haklarında ceza kanunu da uygulanacaktır.

Ecnebi okullarındaki gayrimüslim Osmanlı tebaasından erkek öğrenciler fes giyecekler ve mektep yönetimi tarafından adetlerini yerine getirmeleri engellenmeyecektir. Yabancı okullar için, ders kitaplarından başka, gelen ve Encümen-i Teftiş ve Muayene tarafından zararsız olduğu onaylanmayan kitaplar Maarif Nezareti'nde saklanacak, mektebe verilmeyecektir. Mekteplerin dış kapısının üzerine, Türkçe ve mensup olduğu milletin yazısıyla, mektebin çeşidi, kurucusu ve mensubiyeti yazılacaktır. 
Özetle bu nizamname, yabancı okulların Osmanlı Devleti'ndeki statüsünü gayet ayrıntılı ve açık bir şekilde ortaya koymakta, bu okulların Osmanlı müfettişi tarafından denetleneceğini, sefaretlerin bu denetimi engellemeyeceğini, bu okulların ruhsatlı olması gerektiğini, Müslüman çocukların bu okullara gitmesinin yasak olduğunu, yabancı okul İstanbul'da açılacaksa, diğer şartların yanında padişah izni ve maarifin izni dahilinde ise re'sen, imparatorlukta açılacaksa diğer şartların yanında padişah izniyle açılabileceğini, uyarıya rağmen bu okullarda kanuna aykırı harekete devam edilirse okulun kapatılacağını, öğrencilerin ve yabancı okulların mensup olduğu mezhebin akaidine dikkat edileceğini, yabancı okullardaki Osmanlı tebaası için Türkçe ve Osmanlı Tarihi'nin zorunlu olduğunu, İslam dini, Osmanlı Devleti, padişah ve hukuk-1 mukaddese aleyhinde ve yabancı politikaları lehinde kitap okutmanın ve ögrencilere fesat fikirler telkin etmenin cezayı gerektireceğini, bu okullardaki Osmanlı tebaasının kıyafet ve ritüellerine dikkat edilmesi gereğini, okullar için basılan kitapların şer'an ve siyaseten zararlı olmadığının Encümen-i Teftiş ve Muayene'ce tasdik edilmesi gereğini belirtmektedir.

\section{Önlemler}

21 Eylül 1872 tarihinde Cebel-i Lübnan Mutasarrıflığı'ndan maarife yazılan evrakta, ecnebiler tarafından açılmış olan mekteplerin tatil edilmesi düşüncesiyle önceden bazı masraflara karşılık tutulmuş olan memur maaşlarının \%5'inden oluşan meblağ ile 24 adet mektep açıldığ yapılan düzenleme ile bu $\% 5$ hazineye bırakıldı. Açılan mektepler zor durumda kaldılar. Hükümetin açtığı mekteplerde devam sorunu yaşandı. Ecnebiler tarafindan da ahalinin çocuklarını kendi mekteplerine almak ve ücretsiz öğretim yapmak gibi birtakım teşviklere kalkışıldı. Bu yüzden, bir sonraki yıl bütçesine bu mektepler için bir miktar akçe tahsis olunmaz ise bu mekteplerin kapanmamasına bir çare bulunamayacaktı. Bu durum Meclis-i Maarif'e havale edildiğinde, bundan sonra gereği görüşülmek üzere, bu mekteplerin hangi sınıf mekteplerden olduğu ve her birinde ne çeşit dersler öğretildiği, öğretmen ve hademe-i sairesinin adedi, maaşlarının miktarı, öğrencinin adedi, karşılık olarak ayrılmış paranın miktarı ve bundan böyle aylık ne miktar akçe ayrılması lazım geleceğinin açık olarak bildirilmesi, 21 Ekim 1872 tarihinde, Cebel-i Lübnan Mutasarrıflığı'ndan istendi (MF MKT 6/114).

Anlaşıldığı üzere, yabancı okullara karşı açılan 24 adet okul, ortak masraflarının karşılanamamasından dolayı kapanma tehlikesi yaşamaktadır. Yabancılar da bu durumu değerlendirerek, bölge çocuklarını kendi okullarına alma teşviklerine girişmişlerdir. İstanbul ise gereğini görüşmek üzere okulların çeşidi, dersleri, okullarda istihdam edilenler ve gereken para konusunda Cebel-i Lübnan Mutasarrıflı̆̆ı'ndan bilgi istemektedir.

7 Ekim 1873 tarihi itibariyle Mekteb-i Sultani'ye alınacak ecnebi çocuklarından, düzenin devamı gereği, tam ücret alınması kararı (MF MKT 13/16), devlet okulu olan Mekteb-i Sultani'de yabancı çocuklara bir ayrıcalık gösterilmediğini kanıtlamaktadır.

19 Ocak 1882 tarihinde Rüsumat Emaneti'ne yazılan evrakta, Filibe'de Bulgarca basılan kitapların Selanik Vilayeti dahilindeki Bulgar mekteplerine gönderilmekte ve dağıtılmakta 
olduğu ve Selanik ve Makedonya taraflarındaki $\mathrm{Ulah}^{3}$ mekteplerine dağıtılmak üzere, Romanya konsolosları adına sandıklarla zararlı kitapların getirilmekte ve gümrüklerden muayenesiz geçirilmekte olduğunun bugün haber alındığı ifade edilmekteydi. Bu Bulgarca kitaplardan bir nüshası ele geçirilmişti. Kitabın içeriği Osmanlı Devleti aleyhinde gayet zararlı bulunmuştu. Bu zararlı kitaplardan mekteplere sokulmuş ve dağıtılmış olanlarının hemen toplattırılması için gerekenin yapılması, Selanik Vilayeti'ne bildirilmişti. Bundan böyle, getirilecek bu gibi zararlı dergi ve kitapların içeri sokulmasına meydan verilmemesi için Rüsumat Emaneti tarafından yerel rüsumat memurlarına telgrafla gereken uyarının yapılması belirtilmekteydi (MF MKT 74/50). Tabii ki burada dikkati çeken nokta, Osmanlı Devleti aleyhine zararlı kitapların, Romanya konsolosları aracılı̆̆ıyla, muayenesiz bir şekilde, yurda sokulmakta oluşudur.

1886 y1lına kadar devletin teftiş ve müdahalesinden uzak olan gayrimüslim ve ecnebi okulları müfettiş-i mahsusa tarafından ilk defa bu tarihte teftiş edildi (Kodaman, 1999: 53). Diğer taraftan, yabancı okulları denetleme isteği yanlış anlamalara yol açabilmekteydi. Şöyle ki, Cizvit papazları tarafından açılmış olan mektepler hakkında Maarif Nizamnamesi gereğince hareket edilmesi ve bundan sonra mektep açılması için ruhsat isteyenler olursa asla izin verilmeyerek Bab-1 Ali'ye bildirilmesi hakkında 18 Ocak 1887 tarihli hükmün vilayetlere ve Şehremaneti'ne bildirildiği, 14 Mart 1887'de malumdu (DH MKT 1405/29). Bununla beraber, Dahiliye Nezareti'nden Sisam Emareti'ne 14 Mart 1887 tarihinde yazılan evrakta Cizvit papazlarının rivayet olunan zararlarının önlenmesi için, resmi ruhsatı olmayan Cizvit papaz mekteplerine asla izin verilmeyerek, bundan sonra Cizvitler tarafindan mektep kurulup, açılmasına ruhsat verilmemesi ve resmi ruhsata dayanarak açılmış mektep olmadığı halde bunların da öğretimde Maarif-i Umumiye Nizamnamesi'ne uymaya mecbur tutulup, nizama aykırı bir hal ve hareket meydana getirilmemesi konusunda her zaman gözetim ve teftiş altında bulundurulmalarının Meclis-i Mahsus-1 Vükela kararıyla vilayetlere tebliğ edildiği belirtilmekteydi. Fakat bazı yerlerde vaktiyle ruhsatsız açılmış olan Cizvit mekteplerinin derhal kapatılması için harekete geçilmişti. Bu da şikayetlere konu olmuştu. Halbuki karardan maksat, var olan Cizvit mekteplerinin düzen ve gözetim altına alınarak bundan sonra sayılarının sınırlanması olduğundan, bu mekteplerden ruhsatsız olanlarda öğrencilerin öğretim görmesine izin verilmemeli, bu okulların kurucuları Maarif Nizamnamesi'nin hususi mektepler hakkında yürürlükte olan kaidelerine uygun davranmakla sorumlu tutulmalı, münasip bir müddet zarfinda nizami şartlara uyulmadığı takdirde, o vakit bu gibi mekteplerin kapatılmasına hükümetin hakkı olacağı bilinmeliydi. Buna göre muamele edilmeli ve bundan sonra Cizvit papazlarından mektep açmak için ruhsat isteyenler olursa asla izin verilmemeli, durum Bab-1 Ali'ye yazıyla bildirilmeliydi. Bu, Sadaret'in emriydi. Durum, genelgeyle vilayetlere bildirilmişti. Sisam Emareti de gereğince hareket etmeliydi (DH MKT 1405/29). Burada Cizvit papazlarının okulları hakkında tüm ülkeye gönderilen emir, bu okulların denetim altında tutulmaları, kanuna uygun hareket etmeleri, yenilerinin açılmasına izin verilmemesi ve okulların açılması veya kapanması konularının hükümete bildirilip, sorulmasıydı. Yani bu okulları kapatmak için direkt harekete geçilmemeliydi. Bu bir yanlış anlamaydı.

\footnotetext{
${ }^{3}$ Ulah olarak belirtilen Romenlerin nüfusu Makedonya'da, Sırp istatistiklerine göre 1889 yılında 69.665; Bulgar istatistiklerine göre 1900 y1lında 80.767; Yunan istatistiklerine göre 1904 y1lında 25.101; yine 1904 yılında fakat Türk/Müslüman istatistiklerine göre 99.000 idi (Aydın, 2019: 1589).
} 
Yine 1887 yılında Milel-i Gayr-i Müslim ve Ecnebi Mektepleri Müfettişliği kadrosu ihdas edildi (Kodaman, 1999: 53). Mekatib-i Gayr-i Müslime ve Ecnebiye Müfettişliği Nizamnamesi 6 Eylül 1888 tarihinde yayımlanarak gayrimüslim ve yabancı okulların tabi olduğu denetim şartları bir nizamname ile ortaya konmuş oldu (YPRK MF 1/63).

27 Temmuz 1892 tarihinde Dahiliye Nezareti'nden Selanik Vilayeti'ne gönderilen emir genel olarak gayrimüslim ve ecnebi okullarının teftişi, bu okullara yabancı dil bilen birer Türkçe öğretmeni atanması ve bu okullar için müfettiş istihdamına dairdi (DH MKT 1979/56).

Selanik Vilayeti'nden Dahiliye Nezareti için, 22 Mayıs 1892 tarihinde bir yazı kaleme alınmıştı. Şöyle ki, bu yazı, Selanik’teki Bulgar mekteplerinde devam eden durum ve fesat öğretimin engellenmesini icap eden tedbirlerden olmak üzere gayrimüslim ve ecnebi mekteplerinin tamamen resmi ruhsata bağlanarak, muhalefet edenlerin zorlanması ve Selanik şehriyle ona bağlı olan yerlerde öneme haiz gayrimüslim ve ecnebi mekteplerine maaşları maarif sandığından verilmek, atanma ve işten çıkarılmaları hükümetin inisiyatifinde olmak üzere yabancı dil bilen birer Türkçe muallimi tayini ve vilayete bağlı olan yerlere mütemadiyen teftiş için muvazzaf ve yabancı dil bilen birkaç müfettiş istihdamı ve ayrıntıları hakkındaydı. Buna binaen, Maarif Nezareti ile yapılan görüşmelerin sonunda, resmi ruhsat meselesinin gayrimüslim tebaaya ait olan kısmının bir dereceye kadar halledilmiş olduğu anlaşılmıştı. Ancak ecnebi mekteplerine kalan kısmından dolayı Hariciye Nezareti ile Sefaret arasında sürmekte olan görüşme henüz sonlanmamıştı. Adı geçen mekteplere birer Türkçe öğretmeninin tayini ve muvazzaf müfettişler istihdamının uygun olduğu ancak İslam mekteplerinin, ecnebi mekteplerinin geneline ve gayrimüslim mekteplerinin \%95'ine nispetle daha aşağı durumda olduğu belirtilmekteydi.

Müslüman tebaanın çocuklarının marifette ve bilimde ilerleme sebepleri pek aşağı bir derecede bulunduğundan, bunların esasen ve cidden durumlarının ıslahı hakkında padişah iradelerine uygun hareketle iptidai mekteplerinden başlayarak sslah ve ilerleme çarelerine ait her türlü vesilelere ve teşebbüslere süratle başlandığı sırada gayrimüslim ve ecnebi mekteplerinin düzgün durumlarıyla beraber bir de yabancı dil bilen birçok öğretmenin tayini ve müfettişler istihdamı uğrunda katlanılacak bütün masrafa karşı maarif bütçesinin halihazırdaki mevcudiyeti dayanamayacakt1.

Yabancı dil bilen Türkçe öğretmeni bulunsa bile, birer saatten haftada iki defa mektepte bulunursa, mektebin her durumundan ve öğretiminden haberi olamayacaktı. Öğretmenler Hıristiyan tebaadan seçilirse, ortaya çıkabilecek zararlar gelecekte birkaç kat daha artacaktı. Bu mekteplerin padişah iradelerine uygun olarak daima teftiş altında tutulmaları elzemdi. Maarif müdürü ise yalnız merkez vilayette ikamet ve Selanik'in içinde bulunan mekteplere dikkat etmekle kalmayarak, Selanik'e bağlı olan yerleri dahi teftişe memur ve mecbur bulunacağından, böylece teftişin ve takibin sürekli olarak yapılması ve maarif dairesince Rumeli Vilayeti mekteplerinin teftişlerine mahsus müfettiş istihdam edilmekte olmasıyla, daha ziyade gerektikçe müfettişin icap eden yerlere gönderilerek teftiş işlerinin bir kat daha denetim altına alınması uygun olacaktı. Bunun için gereken yapılmalıydı (DH MKT 1979/56).

Görüldüğü üzere Osmanlı Devleti, Selanik’teki Bulgar mekteplerinde zararlı öğretim yapıldığını tespit ve İslam mekteplerinin, ecnebi mekteplerinin tamamına ve gayrimüslim 
mekteplerinin \%95'ine göre aşağı bir durumda olduğunu kabul etmiştir. İptidai mekteplerinden başlayarak eğitimi sslah etmeye çalışırken ve zaten ecnebi ve gayrimüslim mektepleri de iyi durumdayken, bir de bu mekteplere yabancı dil bilen öğretmenlerin tayinine ve müfettişlerin atanmasına maarif bütçesi dayanamayacaktır. Yabancı dil bilen Türkçe öğretmeni olsa bile, mektepte sürekli bulunamayacak, Hıristiyan öğretmen atansa gelecekte bunun zararı daha fazla olacaktır. O yüzden Osmanlı Devleti, Selanik'te, bu duruma çare olarak, bu okulların teftiş altında bulundurulmasını ancak bu işi maarif müdürünün ve var olan müfettişin yapmasını emretmektedir. Buradan, ekonomik şartların ve imkânların devletin önlemler konusunda hareket kabiliyetini daralttığı da anlaşılmaktadır.

Yine Diyarbakır Vilayeti'nde ecnebi okullarının teftiş edilmesi ve bununla beraber bu okullara karşı Müslüman okullarının üstün hale getirilme çabası görülmekteydi. Şöyle ki, Diyarbakır Vilayeti dahilinde rahipler tarafından açılmış mektepler hakkında evvelce gelen emir ve Sadaret yazısı bilinmekteydi. Bunun üzerine, bu mekteplerde hatıra gelen zararların ortadan kaldırılmasına çare olarak öğretimin teftişi ve İslam iptidai mekteplerinin ecnebi mekteplerine üstün hale getirilmesi, Diyarbakır İdadisi’nin bir kat daha düzenlenmesi ve ecnebilerin yeniden mektepler açmalarına firsat bulamamaları sebeplerinin oluşturulması lüzumunu içeren Diyarbakır Vilayeti'nden gelip, 18 Haziran 1893 tarihli Sadaret üst yazısıyla gönderilen cevabi yazı da malumdu.

Bilindiği üzere, ecnebi mekteplerinin teftişi maddesi, ilgili sefaretlerle Osmanlı Hükümeti arasında diyalog devam ettiğinden, Diyarbakır Vilayeti gibi diğer vilayetler tarafından da bu konuda pek çok şikâyet ve başvuru gelmekteydi. Sonucun çabuklaştırılması için Hariciye Nezareti'ne emir yazılmalıydı. İptidai öğretimi ile ilgili bazı 1slahatların yapılması zaten düşünülmüş olup, iptidai mekteplerinin çoğaltılması yolundaysa, Diyarbakır Vilayeti'nin çabaları görülmekteydi. Diyarbakır İdadisi yakın dönemde yatılıya dönüştürülmüştü. Böylece İdadi'nin bir derece daha düzenlenmesi sağlanmıştı. Ecnebilerin yeni mektepler açmasında, Maarif Nizamnamesi'nin ilgili maddeleri ve geçende çıkan padişah iradesi hükümlerine göre muamele yapılması, mülkiye memurlarına ait olacaktı. Bu yüzden gereği yapılmalıydı. Mekteplerin düzen ve ilerlemesi yalnız maarif memurlarının çabasıyla olamayacağından, mülkiye memurlarının dahi gayret göstermesi gerekmekteydi. Bu durum, Diyarbakır Vilayeti'ne resmi yazıyla tavsiye edilmişti. Ecnebi mekteplerinin teftiş muamelelerinin bir an önce icraata geçirilmesi için gereken sebeplerin oluşturulması çok önemliydi (MF MKT 172/2).

Bununla beraber, Konya Valisi Hasan Hilmi'nin 10 Ocak 1894 tarihinde Maarif Nezareti'ne çektiği telgrafta Niğde ve ona bağl1 yerlerdeki Protestan mekteplerinin padişah iradesi gereği, ruhsatla açılmasına müsaade edilmesi gerektiğinden, bu mekteplerin tahkiki için maarif müdürünün görevlendirilmesi istenmekteydi (MF MKT 192/99). Zaten 1893 tarihli padişah iradesinde de yabacı okullar için ferman alınmasının gerekliliği vurgulanmaktaydı (Uyanık, 2017: 13).

Osmanlı Devleti, Müslüman çocuklarının yabancı okullara gitmesini de önlemeye çalışmaktaydı. Öyle ki, Protestan ve diğer ecnebi mekteplerine Müslüman çocuklarının, özellikle de kız çocuklarının gitmesi ve bunların içinde de gelinlik kızların olması, Yıldız 
Sarayı'ndan Sadaret'e bu durumu oluşturan nedenlerin ortadan kaldırılmasına dair, 24 Ocak 1888 tarihli, II. Abdülhamit'in emrinin yazılmasına neden olmuştu (IDH 1066/83576).

Yine Frenk Katolik mektebinin ödül dağıtma töreninde İslam çocuklarının başları açık olarak huzurda hazır bulunmaları üzerine, bir daha bu mektebe çocuklarını göndermemeleri konusunda babalarına gerekli tembihler yapılmış ve gereğinin yapılması için Adalar Kaymakamlı̆̆ı, durumu Şehremaneti'ne yazmış, bunun üzerine konu, 5 Eylül 1895 'te Maarif Nezareti'ne iletilmişti. $\mathrm{Bu}$ işin araştırılması için maariften gönderilen memur, Adalar Kaymakamlığı' 'na ulaşmıştı. Ancak bu konudaki tembihlere Şura-i Devlet Azası'ndan Baki Bey Efendi Hazretleri'nin itaat etmediği ve çocuğunu Frenk Katolik mektebine göndermeye devam etmekte olduğu anlaşıldığından, ne şekilde davranılmasının lazım geleceğinin belirtilmesine dair, Adalar Kaymakamlığı'ndan gelen evrak, Şehremini tarafindan 30 Ekim 1895'te Maarif Nezareti'ne gönderilmişti (MF MKT 294/13).

19 Kasım 1895 tarihinde Maarif'ten Şehremaneti'ne yazılan cevapta, durumun Mekatib-i Gayr-i Müslime ve Ecnebiye Müfettişliği'ne havale edildiği ve sonuçta aşağıdaki karara varıldığı belirtilmekteydi.

İslam çocuklarının gayrimüslim ve ecnebi mekteplerine devam ettirilmemesi defalarca her tarafa tebliğ edilen padişah iradesi hükümlerinden olup, Maarif Nezareti'nce yapılacak muamele ise çocukların babalarına gerekli tebligatın yapılmasından ibarettir. $\mathrm{Bu}$ da yapılmış olduğundan ve bu yasağın korunması da hükümet memurlarının vazifesinden olduğundan, çocuğunu Frenk Katolik mektebine göndermekte ve tembihlere uymamakta olan Baki Bey Efendi Hazretleri'ne durumun tekrar tebliği ve şayet yine uymazsa konunun Bab-1 Ali’ye yazılmas1 gerekecektir (MF MKT 294/13).

Anlaşıldığı üzere, Şura-yı Devlet gibi önemli bir kurumun üyesi çocuğunu Frenk Katolik mektebinden almamakta ssrar etmekte ve yazışmalarda da kendisine Hazretleri unvanı ile yer verilmektedir. Maarif Nezareti durum hakkında yetkisi olmadığından konuyu ancak Bab-1 Ali'ye iletebileceğini ifade etmektedir. Çünkü çocuğunu okuldan almayan Şura-yi Devlet üyelerinden Baki Bey Efendi Hazretleri'dir. Ayrıca çocuklarını bu okula gönderen Müslüman veliler, devletin tepki gösterme ihtimalinin yüksekliğini göze alarak, bu çocukların başları açık olarak Fransız mektebinde bulunmalarını kabul etmiş gözükmektedirler.

Bununla beraber, 4 Nisan 1896'da Maarif'ten Beyrut Vilayeti'ne yazilan evrakta, Müslüman çocuklarının gayrimüslim ve ecnebi mekteplerine devamlarının padişah iradesiyle yasaklandığı belirtilmekte, buna rağmen Antakya eşrafından Saadetlü Rıfat Efendi’nin oğlu Saci Efendi'nin, Beyrut'taki Maruni mektebine gittiğinin Halep Vilayeti tarafından bildirildiği ifade edilmekteydi. Durum, Mekatib-i Gayr-i Müslime ve Ecnebiye Müfettişliği'ne havale edildi. Bu konudaki yasaklara uymanın lüzumu belirtilerek, Saci Efendi'nin mektepten çıkarılması ve velisine gönderilmesi ya da orada münasip bir İslam mektebine devam ettirilmesi kararına varıld1 (MF MKT 309/6).

Bitlis Maarif Müdürü Ahmet Hilmi, 8 Ağustos 1898 tarihinde, Maarif Nezareti'ne, ecnebi ve gayrimüslim okullarının resmi ruhsata bağlanmaları hakkında yapılacak muamelenin iznine dair bir telgraf çekmiştir. 28 Kasım 1898 tarihinde Maarif’ten, Bitlis Maarif Müdürlüğü'ne yazılan cevabi evrakta, Mekatib-i Gayr-i Müslime ve Ecnebiye Müfettişliği'nin görüşünün 
alındığı ve ecnebi mektepleri hakkında Bab-1 Ali ile ecnebi sefaretleri arasındaki diyalogdan şimdiye kadar bir sonuç çıkmadığı belirtilmektedir. Bundan dolayı şimdilik ecnebi okullarının birdenbire resmi ruhsata bağlanmaları için teşebbüs edilememesi doğaldır. Fakat bu okullar kendiliğinden ruhsat talep ederlerse ya da hükümetin teşvikleri ve sağladığ 1 kolaylıklar sonucu ruhsat almak isterlerse bunlara usulünce ruhsat verilip, gereken teftişin de yapılması lazım gelecektir. Ona göre gereği yapılmalıdır (MF MKT 477/49). Yani görüşmeler sonlanmadığından, hükümet, ecnebi okullarının derhal resmi ruhsata bağlanmalarını istemek yerine, kendi istekleriyle ruhsat talep etmelerini yeğlemektedir.

3 Ağustos 1904 tarihinde ise Osmanlı İmparatorluğu'nun neresinde olursa olsun, gerek Osmanlı tebaası, gerekse ecnebi tebaası tarafından padişahın izni alınmadıkça, mektep kurulmasına ruhsat verilmemesinin padişah iradesi gereği olduğu fakat buna rağmen bazı yerlerde ruhsatsız mektepler inşa edildiği anlaşıldığından, bundan sonra padişah iradelerinin hükümlerine uygun hareket edilmesinin Şura-yı Devlet tarafından hatırlatılmakta olduğu, Sadaret yazısıyla ifade edilmekteydi (DH MKT 2605/87). Buradan 1904 yılı itibariyle, gerek Osmanlı tebaası, gerekse ecnebi tebaasının, padişah iradelerine rağmen, ruhsatsız okullar açmaya devam ettiği anlaşılmaktadır. Yine bu tarihte Osmanlı Hükümeti, Müslüman çocuklarının Hıristiyan mekteplerine gitmemesi için bir karar almıştı. İstanbul'da yabancı okullara giden Müslüman çocuk varsa bunların engellenmesi için polis aracılığıyla velilerine gereken tembihin yapılması da alınan önlemlerdendi (Uyanık, 2017: 14).

Diğer taraftan, resmi ruhsatı olan okullarda da konsoloslar adres gösterilerek, teftiş engellenmeye çalışılmaktaydı. Şöyle ki, Manastır'daki Protestan kız mektebinin teftişinde, mektep müdürünün, mektep işlerinin Manastır Avusturya Konsolosu tarafından idare edildiğini; bundan dolayı da konsolostan başka bir tarafin ne suretle olursa olsun, isteyeceği açıklamaya cevap verilmesinin ya da teftişi kabul etmenin uygun olmayacağını beyan etmesi; buna ilave olarak da konsolosun, müdürün talimat, kanun hükümleri ve örneklerine aykırı olan bu ifadeleri desteklediği görülmekteydi. Bu konuda Sefaret aracılığıyla konsolosa tebligat yapılması gereğine dair Maarif Nezareti'nin 8 Temmuz 1905 tarihli evrakı 23 Temmuz 1905 tarihinde Sadaret'ten Hariciye Nezareti'ne gönderilmekte ve gereğinin yapılması istenmekteydi (BEO 2628/197046).

\section{Protestan Okulları Tabiri}

Osmanlı topraklarında Amerikalıların ve İngilizlerin açtıkları mekteplere Protestan okulları denmekteydi (Akyüz, 2001: 161). 1850 yılında Amerikalıların ve İngilizlerin etkisiyle Protestan Ermeniler, Osmanlı Devleti'nde bir millet olarak kabul edildiler ve bundan sonra Amerikan misyonerleri özel okulları aracılığıyla Ermenilerin arasında Protestanlığın yayılması için daha fazla çaba gösterdiler (Yıldız, 2009: 39). Dolayısı ile Osmanlı Devleti'nde gayrimüslim bir millet statüsü daha ortaya çıkmış oldu.

Protestan okulları hakkında Padişah II. Abdülhamit, Maarif Nazırı Zühdü Paşa'dan bilgi istemiş ve Zühdü Paşa tüm ülkeden bilgi toplayarak bu bilgileri padişahın sekreterliğine, 20 Temmuz 1893 'te, bir tezkere ve ona bağlı bir defter halinde sunmuştur. Zühtü Paşa, erkek ve kızlara mahsus yatılı ve gündüzlü toplam 392 adet Protestan ve Amerikan mektebinin olduğunu belirtmiştir (Akyüz, 1970: 121, 122, 123). 


\section{Amerikalıların Eğitim Faaliyetlerinin Denetimi}

1851-1860 arasında Amerikan Board bünyesinde faaliyetlerine devam eden ve faaliyet alanı Mezopotamya olarak belirlenmiş olan Asur Misyonu, beklenen başarıyı elde edememişti (Alan, 2019: 19, 45). Suriye ve Beyrut'ta ise Amerikalı Protestan misyonerlerin hedef toplumu Nusayrilerdi (Uyanık, 2014: 38). II. Abdülhamit, Protestan misyoner okullarının Aleviler, Yezidiler, Dürziler ve Nusayriler üzerindeki muhtemel etkilerini azaltmak için Sünniliği anlatan gezici ögüt kurulları vazifelendirmişti. Ayrıca Nusayrilerin Protestan okullarına gitmemeleri için modern okulları da yaymaya çalıştı. Adana Vilayeti'ne bağlı Osmaniye, Kozan, Mersin ve İçel sancaklarında 15 adet erkek okulu, Protestan misyonerlerinin Mersin ve Tarsus'taki kız okullarının karşıllı̆ında 2 tane kız ortaokulu kurulması için uğraşılmaktaydı. Ayrıca bölgedeki Nusayri öğrencilerin Hıristiyan okullarına gitmemeleri için Adana, Tarsus ve Mersin bölgesindeki Nusayri yerleşmelerinde bina tutularak, dinin yayılması amacıyla 25 okulun açılması siyasal bir gereklilik olarak görülmekteydi. II. Abdülhamit, devlet ödeneği olmadığ1 halde, kendi gelirinden okullar açarak, Protestan misyonerlerin eğitim anlamında Nusayriler üzerinde oluşturmaya çalıştıkları olumsuz etkiyi kırmaya çalışmaktaydı (Uyanık, 2014: 52, 53). Anlaşıldığı üzere, bölgede Protestan okullarının denetiminden ziyade, onlara karşı okul açılması ve dini konuların anlatılması ön plana çıkmaktaydı.

Osmanlı eğitim teşkilatında dönemin gereklerine ve kazanılan tecrübelere göre zaman zaman düzenlemeler yapılmaktaydı. Bu anlamda nezaretin sadrazama arz ettiği layihada genel olarak dışarıdan getirilen ve gümrüklerde bulundurulan kitap ve diğer eserlerin incelenip, basım ve yayımlarına izin verilip verilmemesi konusunun maarif idaresinin önemli görevlerinden olduğu ifade edilmekte, Telif ve Tercüme Dairesi ile Matbaalar İdaresi'nin birleştirilip, var olan müfettişleri de oraya bağlayarak, Teftiş ve Muayene Encümeni'nin kurulması belirtilmekteydi (Kodaman, 1999: 31).

Telif ve Tercüme Cemiyeti ile Matbaalar Dairesi birleştirilerek adı Encümen-i Teftiş ve Maarif; yani Encümen-i Teftiş ve Muayene oldu (Mahmud Cevad İbnü'ş-Şeyh Nafi, 2002: 184).

Encümen-i Teftiş ve Muayene Heyeti'nin kurulması için padişah iradesi, 31 Aralık 1881 'de çıktı. Heyetin görevi, Osmanlı topraklarında basılacak Türkçe, Farsça, Arapça, Bulgarca, Rumca, Ermenice kitap ve broşürlerle ilgilenmek, yabancı ülkelerden gelen farklı dillerde yazılmış kitapları gümrüklerde muayene etmek ve bütün okulları teftiş etmekti (Kodaman, 1999: 32).

Osmanlı topraklarında Amerikalıların eğitim faaliyetlerini denetleme konusunda zararlı kabul edilen yayınları engelleme çabaları, önemli bir alanı işgal etmekteydi. Çünkü bu yayınlar dağıtılabilmekte ve mekteplerin kütüphanelerinde de bulundurulabilmekteydi. Şöyle ki, diyaneti İslam aleyhinde düzenlenmiş bir risalenin, Fincancılar Yokuşu'ndaki Amerikan kütüphanesinde ve sair kitapçılarda mevcut olduğunun haber alınmasıyla, gerek bunların gerekse sairlerinin seri bir şekilde toplattırılması konusunda Vaporidi Efendi'nin memur tayin edildiği ve belirtilen risalenin de gönderildiğine dair Zaptiye Nezareti’nin 4 Şubat 1887 tarihli evrakına ek olarak yazılmış cevapta, Amerikan Sefareti'nden tercüman çağrılıp, Polis Meclisi üyelerinden Nuri Efendi memur edilerek, Vaporidi Efendi de olduğu halde yapılan araştırmada 
Amerikan mektebi kütüphanesinde bahsedilen risale ve daha başka zararlı kitapların bulunduğu fakat bunların teslim alınamadığı ifade edilmekteydi. Durum, Hariciye Nezareti'ne iletildi. Amerikan Sefareti risalelerin varlığını inkar etmek istemekteydi. Oysa araştırma süreci ve risalelerin varlığı, komiser ve müfettiş raporuyla sabitti.

Amerikan Sefareti birkaç sene önce misyonerlerin Atina'dan gelmiş Rumca bir kitabı satmaya başladıklarını fakat bu kitabın beğenilmeyerek, satışından vazgeçildiğini ifade etmekteydi. Kütüphanede de zararlı bir şey yoktu. Sefaretten memur hazır olmadıkça, kütüphaneye girmek yasaktı. Resmi olmadığ 1 ve maiyetinde polis bulunmadığ 1 takdirde de kütüphane kapısı memurlara açıktı. Amerikan Sefareti zararlı risalelerin varlığını inkar etmekteydi. Bunun üzerine tekrar bir araştırma yapılmalıydı. Ancak kütüphaneye resmen girilip, zararlı kitapların araştırılması ve teftişin yapılması hakkıyla ilgili muameleler Zaptiye Nezareti'ne, ortaya çıkacak siyasi bir durum ise Hariciye Nezareti'ne ait olacaktı. Bu yüzden zararlı eşya için ecnebi ikametgahlarına girilmesi hakkında yürürlükte olan durumun, bu meselede dahi uygulanması doğal kabul edileceğinden, Zaptiye Nezareti'ne cevap yazılmalıydı. Bu karar, 12 Temmuz 1887 tarihinde Meclis-i Kebir-i Maarif mührüyle onay için üst makama yazıldı (MF MKT 94/46).

5 Ağustos 1887 tarihinde Zaptiye Nezareti'ne yazılan, Zaptiye Nezareti'nin 1887 tarihli cevabına cevapta, araştırmanın yapılmasından ve risalelerin varlığının belirtilen kişilerin raporuyla sabit olmasından dolayı, tekrar araştırma yapılması gereken kütüphaneye resmen girilip, zararlı kitapların araştırılması ve teftişi hakkında usulünce yapılacak muameleler, Zaptiye Nezareti'ne ait hususlardan bulunduğundan, ecnebi ikametgâhlarına girilmesi hakkındaki usule uygun olarak gereğinin yapılması belirtilmekteydi. Yani Amerikan kütüphanesine tekrar girilip, zararlı yayınların aranması ve teftişin yapılması istenmekteydi (MF MKT 94/103).

Burada Amerikan mektebi kütüphanesindeki komiser ve müfettiş raporuyla sabit zararlı yayınların teslim alınamadığı ve Amerikan Sefareti'nin devreye girerek bu yayınların olmadığını ifade ettiği ortaya çıkmaktadır. Dolayısı ile raporla sabit olmasına rağmen, kütüphanede tekrar bir teftiş yapılacaktır.

Amerikan Sefareti'nden 12 Şubat 1893 tarihinde, Amerikan Misyoner Cemiyeti'nin Osmanlı şubesi tarafından Bulgarca basılan kitapların dağıtılmadan önce muayenesi konusunda, Encümen-i Teftiş ve Muayene tarafından gecikmeye sebebiyet verildiğini, bazı ifadeleri ve bu encümenin azasının yeterliliğinin yükseltilmesiyle beraber şimdiki sansür memurunun ehliyetsiz olduğunu ve Amerikan Misyoner Cemiyeti'nin yayınının dini bir içeriği olduğunu, bu yüzden belirtilen kitapların sansür makamında tekrar gözden geçirilmesini ve Hıristiyan üye dahil olmak üzere bir komisyon kurulması ricasını ve sansür memurunun uygun olmayan denetim çiziklerine dair örnekleri içeren evrakı hükümete gönderdiği görülmekteydi. Evrakın içeriğine göre gereğinin yapılması, sadrazamın iradesine bağlıydı. Hariciye Nezareti konuyu 20 Şubat 1893 'te Sadaret'e bildirdi (BEO 177/13272).

21 Şubat 1893'te gereğinin yapılması için Sadaret'ten Maarif Nezareti'ne bir evrak yazıldı (BEO 159/11885). Halbuki encümen, konuya dair cevabi bir layiha hazırlamıştı ve bu 
layiha 20 Şubat 1893 'te Maarif'ten Sadaret'e gönderilmişti. Bunun üzerine 29 Mart 1893'te icabının yapılması için Sadaret, durumu Hariciye Nezareti'ne iletti (BEO 117/13272).

Burada Amerikan Sefareti'nin, Encümen-i Teftiş ve Muayene üyelerinin yeterlik derecesini az bulduğu, sansür memurunu ise yetersiz gördüğü, kitapların tekrar incelenmesini istediği ve Huristiyan üyenin de olduğu bir komisyon kurulmasını belirttiği ve sansür memurunun işaretlemelerini kabul etmediği görülmektedir. Özetle Amerikan Sefareti, Osmanlı Hükümeti'nin denetim komisyonunu ve üyelerinin çalışmalarını yeterli görmemekte ve yaptıkları denetimi kabul etmemektedir.

Bununla beraber, Amerika'da Newyork şehrinde basılmış olup, Osmanlı topraklarında bulunan ecnebi misyoner heyetlerinin iş ve hareketlerini ve özellikle Hıristiyanların Osmanlı idaresi tarafindan sokuldukları durumdan kurtarılmaları konusunda ecnebi misyoner heyetleri tarafindan harcanan mesaiye dair Bir Asır Sonra Ecnebi Misyoner Heyetleri adlı İngilizce kitabın saltanat ve diyanet-i İslamiye aleyhinde kötü niyetle yazıldığı, dinen ve siyaseten gayet zararlı bulunduğu ifade edilmekteydi. Aralık 1894'te kitabın yurda sokulmasının yasaklanması ve kitapçı dükkânlarındakilerin de ele geçirilmesi konusunda padişah emrinin olduğu Maarif Nezareti tarafından ifade edildi. 15 Aralık 1894'te de olağanüstü zararlı olan kitabın nüshalarının içeri girmesinin ve dağıtımının engellenmesi, Maarif Nezareti tarafından belirtildi (MF MKT 239/32).

19. yüzyılın sonlarında Anadolu'da Amerikan misyonu bulunan şehirlere bakıldığında, Kayseri ve Sivas'ın da bunlara dahil olduğu görülmekteydi (Vahapoğlu, 2005: 41). Talas'ta ise 1889'da bir erkek, bir de kız okulu vardı (Tozlu, 1991: 139). Görüldüğü üzere, Amerikalıların Orta Anadolu'ya ilgileri aşikârd1.

16 Şubat 1894 'te Ankara Valisi Memduh tarafından Sadaret'e çekilen şifreli telgrafta, dünkü gün Sivas valisinden gelen şifreli telgrafta, Kayseri'de Müslümanların Ermenileri katledeceklerine dair bildiriler asıldığının, Amerikalı Mösyö Fonsur tarafından Sivas'ta ikamet eden Amerikan konsolosuna gönderilmiş mektupta bildirildiğinin beyan edilmesi üzerine, hemen Kayseri Mutasarrıflı̆̆ı'ndan bilgi istendiği ifade edilmekteydi. Gelen cevapta, şimdilik aykırı bir durumun olmadığı ve Protestanların Hıristiyan Osmanlı tebaasını aldatarak mektepler kurmaya çalıştıkları ifade edildi. Ardından yine Kayseri Mutasarrıflığı'ndan gelen diğer şifreli telgrafta Mösyö Fonsur'un şimdiye kadar hiç kendisine gelmemiş iken Protestan rahibi Keropa ile saat 8 civarında yanına gelerek, hükümetin icraatına teşekkür ettikten sonra bazı ecnebi gazetelerinin Osmanlı ülkesi aleyhinde yazılar yazmakta olduğunu, kendisinin ise bundan müteessir bir halde bulunduğunu ve kendisinin de ecnebi olmakla bir zanda bulunmadığını ifade ettiği ve ayrılışından bir saat geçince sebepsiz yere çarşıdaki Ermenilerin dükkânlarını kapamaya başladıkları, bunun üzerine derhal asker ve zaptiyelerin buralara gönderildiği, dükkân sahiplerinin birbirlerine bakarak dükkânlarını kapattıkları, verilen nasihat üzerine mevcut olanların dükkânlarını açtıkları, saat 11'e geldiği için yarın dükkân açacak olanlara da bu dükkân kapama durumunun sorulacağı bildirilmekteydi (A\}MKT MHM 724/4).

Bundan sonra Ankara valisi, Sadaret'i bilgilendirmeye devam etmekteydi.

Bilindiği üzere Protestanlar kaç seneden beri mektep kurarak, Ermenilere fesat ders vermekten geri kalmadıklarından, fesatlığın tesiri her yerde ortaya çıkmaktadır. Kendi 
mezhebine inanan ve devletine tabi olan, sadık, ağırbaşlı, terbiyeli Ermeniler dahi şu işlerden cidden şikayet etmekte, sanat ve ticaretlerinde zarara uğramaktadırlar. Komitalar kendilerinden para talep etmekte ve vermedikleri takdirde de ölümle tehdit etmektedirler. Diğer taraftan da hükümete karşı asılsız şüphelere duçar olmaktadırlar.

Devletçe bir çare bulunup da Protestan mektepleri tatil olunursa Ermeni "melanet" sahiplerinin iki eli kırılmış olur. Komitalar dahi umutsuz kalırlar. Devlete sadakat gösteren Ermeniler kendi aralarındaki fesatları yavaş yavaş hükümete bildirirler (A\}MKT MHM 724/4). Anlaşıldığı üzere Ankara valisi, Protestan mekteplerinin kapatılmasıyla, Ermeni melanet sahiplerinin durdurulacağını ve Ermeniler içerisindeki fesatların tespit edileceğini belirtmektedir.

Ankara valisinin bu telgrafi, İstanbul'da hususi komisyona havale edildi. Düzenlenen mazbatada, Fonsur'un asılsız telgraf çekmesi, ardından hükümet dairesine gelerek aldatıcı ifadeler kullanması, o sırada da dükkânların sebepsiz yere kapanması, kendisinin fesatlığını inkâr edenlerden olduğuna delalet ettiği belirtilmekteydi. Buna rağmen, Ankara valisinin telgrafında Fonsur'un hüviyeti, durumu ve sıfatı hakkında yeterli bilgi olmadığından, durum, tarafsızca araştırılarak, fesat sahiplerinden olduğu belirlendiği halde Fonsur'un münasip bir şekilde oradan gönderilmesi sebeplerinin oluşturulması beyan olundu. Ayrıca ecnebi ve Hıristiyan mektep programlarının maarif memurları marifetiyle teftiş edilerek, içeriği zararlı olanların öğretimlerinin men edilmesi hakkında Meclis-i Mahsus-1 Vükela tarafından verilen karar 25 Şubat 1894 tarihli yazı ile bildirilmiş olmakla beraber, mektepler hakkında belirtildiği gibi gereğinin yapılması ve Fonsur'un durumunun araştırılarak elde edilecek bilgilerin ifade edilmesi, 26 Şubat 1894'te Sadaret'ten Ankara Valiliği'ne yazıldı (A\}MKT MHM 724/4).

Görüldüğü üzere Osmanlı yönetimi Fonsur'un hakkında objektif bir araştırma, net delil ve bilgi istemekte, Ankara valisinin Protestan mekteplerinin tatil edilmesi isteğine de, yabancı ve Hıristiyan mektep programlarından zararlılarının men edilmesi şeklinde cevap vermekte, tabii ki bu okulların maarif memurları tarafından teftiş edildikten sonra bu kararın uygulanmasını belirtmektedir.

Balkanlar, İngilizlerle beraber, Amerikan Protestan misyonerlerinin Yakın Doğu ve Avrupa politikalarında değerli bir alan olarak 19. yüzyılın başlarında önemli bir hale gelmiştir. Bulgarlar arasında yapılan çalışmalar ise Protestanlık için Bulgaristan'ın önemli bir bölge olduğunu ortaya koymuştur. 19. yüzyılın ortalarında Bulgaristan, Protestan misyonerlerinin gözden çıkaramayacakları bir saha olarak gözükmektedir. Osmanlı Devleti'nin Avrupa topraklarında, Bulgaristan, Protestan misyonerleri için en aktif çalışılan yer denebilir. Elbette Amerikan misyonerleri de Bulgarlara göstermeleri gereken ilginin farkındaydılar (Aydın, 2008: $35,37,38)$.

Amerikalıların Osmanlı topraklarındaki eğitimlerinin sembol kurumu olarak ise Robert Kolej görülebilir. 1863’te öğretime başlamış olan Robert Kolej, Bulgarlara olduğu gibi, Ermenilere de aşırı ilgi duymuştur. 1863 öğretim yılı başında kayıtlı olan 20 öğrenciden 2'si dışındakiler Osmanlı gayrimüslimleridir (Tozlu, 1991: 229, 235). En fazla Bulgar ve Ermeni öğrencileri almış olan Robert Kolej'e, 1879 yılında toplanan Bulgar parlamentosu, yetiştirdiği Bulgar çetecileri, Bulgar devlet adamları ve aydınları için teşekkür etmiştir (Akyüz, 2001: 161). 
40 yılda koleje 2500 öğrencinin kayıt olduğu görülmektedir. Bunlardan 195'i Bulgar, 144’ü Ermeni, 3'ü Alman, 2'si Yahudi ve 1'i de Türk olmak üzere 435'i lisansüstü eğitim yapmıştır. Yani kolejin 40 yılında 1 Türk lisansüstü eğitim yapmıştır. Bu kişi daha sonra kolejin Türkçe bölüm başkanı ve müdür yardımcısı olan Bektaşi şeyhinin büyük oğlu Hüseyin Bey'dir; ki kendisi Lozan'a İnönü tarafından sekreter olarak götürülmüştür (Tozlu, 1991: 239).

Osmanlı Devleti'nin, iddialar sebebiyle koleji denetleme çabaları da resmi yazışmalara yansımıştır. Şöyle ki, Zaptiye Nezareti'nden, 16 Eylül 1902'de, Dahiliye Nezareti'ne yazılan evrakta, Rumelihisarı'nda bulunan Robert Kolej adlı Amerikan mektebinde tahsil maksadiyla İstanbul'a gelmek isteyen Ermenilerin izinleri için öteden beri Amerika Sefareti tarafindan müdahale edildiği belirtilmekteydi. Ayrıca bu defa mektepte küçük çocuklar için bir şube açıldığı ve Sefaret tarafından, Anadolu'dan 8-9 yaşlarındaki Ermeni çocukların çekilmeye çalış1ldığ1, bu konuda hükümetin bir karar vererek bu kararın neticesinin bildirilmesi hususu ifade edilmekteydi (DH TMIK M 132/52).

Zaptiye Nezareti'nin bu evrakı üzerine Tesri-i Muamelat Komisyonu tarafindan, Maarif Nezareti'ne 30 Eylül 1902'de birtakım sorular soruldu.

Robert Kolej, Maarif Nizamnamesi hükümlerine göre mi teftiş ettirilmektedir? Vilayetlerde bulunmaları gereken çocukların taşradan kendi kendilerine gelerek, Robert Kolej'de talim ve terbiyeleri caiz olamayacağından bu gün bu okulda taşralı ne kadar çocuk bulunmaktadır ve bunlar ne suretle getirilmişlerdir? (DH TMIK M 132/52)

Bu sorular ve Zaptiye Nezareti'nin evrakı üzerine, Maarif Nezareti 30 Ekim 1902'de, Dahiliye Nezareti'ne cevap yazmıştır. Şöyle ki, tahkikat için koleje gönderilen Müfettiş Halid Bey Efendi tarafından bir rapor verilmiştir. Verilen raporda, Robert Kolej'e eskiden beri İstanbul ve taşradan tahsil için gayrimüslim çocuklarının gelmekte olduğu, mektebin gayrimüslim tebaa çocuklarına mahsus olmayıp, ecnebi memleketlerden gelen çocuklara da açık olduğu, mevcut talebenin çoğunluğunu ecnebi çocukların oluşturduğu, Osmanlı vilayetleri ile çeşitli yerlerden gelen çocukların sırf kendi arzu ve hevesleriyle geldikleri ve mektep idaresinin bu konuda bir teşvikinin olmadığı, kendi kendine talebe çekilmeye asla çalışılmadığı, kayıt edilecek çocukların üst sınıflar için 14 ve ilkokul için 10 yaşından aşağı olmamasının mektebin tüm nizamatından bulunduğu, taşradan gelen Ermeni çocuklarından doğrudan doğruya gelenlerden başka mektep idaresine başvuranlar olursa, sırf kendilerine kolaylık olmak üzere, mektep ya da konsolosluk vasitasıyla Zaptiye Nezareti'ne müracaat edilerek, izinleri için müsaade alındığı ve bu yoldaki müracaatın yalnız bu seneye mahsus olmayıp, 8-10 seneden beri devam ettiği, bu sene dahi koleje taşradan 4'ü Ermeni, 3'ü Rum olmak üzere 7 çocuğun geldiği, yalnız Tekfurdağı'ndan gelecek bir Ermeni çocuğun izni için geçenlerde konsolosluk tarafından Zaptiye Nezareti'ne müracaat edildiğinin zannedildiği ve mektebin her zaman maarif memurlarına açık olduğu bilgilerinin Robert Kolej'in Genel Müdürü Amerikalı Dr.Vojirin tarafından ifade edildiği belirtilmekteydi. Ayrıca Müfettiş Halid Bey ile kolejin müdürü, mektebin sınıflarını ve diğer yerlerini dolaşmışlar, Halid Bey bu sene ve geçen sene taşradan gelen gayrimüslim çocukların isimlerini beyan eden pusula ile mektebin nizamnamesinden bir örneği müdürden almıştır. Gayrimüslim tebaa çocuklarından böyle küçük yaşta birtakım çocukların mektepte eğitim-öğretim görmeleri dikkat çeken bir durum ise de, mektep müdürünün yukarıda belirtilen ifadesinden anlaşıldığı üzere mektebe bu yolla öğrenci çekilmesi 
yeni bir durum olmadığından, bu konuda bundan sonra Zaptiye Nezareti'nce ve Osmanlı vilayetlerince münasip bir şekilde gereken tedbirler alınarak, gelecek öğrencilerin teftiş miktarına önem gösterilmesi gerekmektedir.

Kolejin yeniden açılacağ 1 daha önceden haber alınan şubeye gelince, öğretmenlere mahsus olarak birkaç oda yapılması için 24 Nisan 1900 tarihinde Sadaret yazısıyla tebliğ edilen padişah iradesi gereğince inşaata ruhsat verilmiş iken, bu ruhsat üzerine kolej müdüriyetinden sıbyan öğrenciye mahsus olmak üzere bir bina inşasına girişildiği İstanbul Belediyesi tarafından bildirildiğinden, padişah iradesi haricinde, inşaatına başlanılan genişletmelerden dolayı, hükümet tarafından icabına bakılmak üzere, durum, maarif tarafından hükümete bildirilmişti.

Mektebin bu sene düzenlenen diploma dağıtma töreninde müdür vekili tarafından yapılan konuşmanın bazı kısımlarında mektebin bahçesi civarında, yeniden inşa edilen diğer bir binanın, geçen Eylül'de açılacağının ifade edildiği, Maarif Nezareti adına memur olarak hazır bulunan müfettiş tarafından raporla beyan edilmişti.

Durum 22 Temmuz 1902 tarihinde Maarif Nezareti tarafindan Sadaret'e arz edilmiş olduğundan, bu defa da belirtilen şubenin açılmış olduğu müfettişin ifadesinden anlaşıldığından, durumun cevap olarak Dahiliye Nezareti'ne bildirilmesi, Mekatib-i Gayr-i Müslime ve Ecnebiye Müfettişliği tarafindan ifade edilmektedir. Ayrıca çocukların isimlerini beyan eden pusulanın tercümesi de gönderilmiştir (DH TMIK M 132/52).

Pusuladaki çocuklar şunlardır:

\section{“Geçen Senelerde Mektepte Bulunan Şakirdan}

Serop Agamciyan Bursa Ermeni, Kaloset Arabyan Trabzon Ermeni, Margos Bakırciyan İzmir Ermeni, Mardiy Balyosyan İzmir Ermeni, Zara Daverdiyan İzmir Ermeni, Hagop Hagopoviç Tekfurdağ Ermeni, Hagob Hagobyan Eskişehir Ermeni, Acidis Garagori Yanya Rum, Konstantin Gorganşis Musnisa Rum, Mencail Kara Yorgi Italya Rum, Kotortinosnis Zesidis Şeyatesta Rum, Çorçi Delyani Sakız Rum, Pelatodya Mandopolo Tekfurdağı Rum, Tersisi Karabetyan Arslanbey Ermeni, Etnasidis Çisavaralis Ervani Tohori Rum, Hiristos Kapusos İzmir Rum, Evangelos Hacı Andra Musnisa Rum, Padalos Konstantinidi Gelibolu Rum

\section{Vilayatdan Gelmiş Olanlar}

Dikran Kopomaclyan Haleb Ermeni, Luis Kuyumcuyan İzmir Ermeni, Andreas Mefalos Gelibolu Rum, Karabet Papazyan Tekfurdă̆ Ermeni, Karabet Slvaciyan Kayseri Ermeni, Dimitri Surlanfa Sakız Rum, Nişan Tokatllyan Giresun Ermeni, Eşil Teryandafilos Gelibolu Rum, Vartan Yeramiyan Van Ermeni, Konstantin Zoeyidis Gümülcine Rum

\section{Vilayatdan Yeni Gelmiş Olan Şakirdan}

Jiran İplikçiyan İzmir Ermeni, Haristoya Kasabyan Ankara Ermeni, Odis Esperyadis Bursa Rum, Mehran Mehsudyan Beyrut Ermeni, Aleksandır 
Yorganioğlu Sivas Rum, Ozanis Odyan Ankara Ermeni, Palasof Giresun Rum " (DH TMIK M 132/52).

Gayrimüslim çocukların isimlerinin yazılı olduğu bu pusulaya bakıldığında, son dönemde Robert Kolej'e vilayetlerden Rum çocuklara nazaran, Ermeni çocukların daha fazla ilgi gösterdiği görülmektedir.

Dahiliye Nezareti Tesri-i Muamelat Komisyonu ifadesiyle, 16 Kasım 1902'de, Zaptiye Nezareti'ne, bundan sonra Zaptiye Nezareti'nce ve Osmanlı vilayetlerince münasip bir şekilde gereken tedbirlerin alınarak, gelecek talebenin azaltılmasına önem verilmesini ve diğer teferruata dair Maarif Nezareti'nin cevabi yazısının gönderildiğini ve bu yazının içeriğine göre mütalaanın bildirilmesini ifade etmektedir (DH TMIK M 132/52).

Anlaşıldığına göre, Robert Kolej, iddialar üzerine teftiş edilmiştir. Öğretmenlere birkaç oda yapmak için ruhsat alınıp, mektebin bahçesi civarında küçük çocuklara mahsus bir bina inşa edildiği ve okula yıllardır İstanbul ve taşradan çocukların geldiği ortaya konmuştur. Zaptiye Nezareti ve Osmanlı vilayetleri okula gelecek çocuk sayısının azaltılması konusunda gereken tedbirlerin alınması için yetkilendirilmiştir. Dolayısı ile Osmanlı Devleti bu koleje fazla çocuk gelmesinden rahatsızdir.

Bununla beraber, Amerikan Kız Koleji’ni bitiren ilk Türk kızı olan Halide Edip’i koleje yazdırmak için babasının adresini değiştirmesi, babasının kayıt için Halide 7 yaşında iken koleje başvurması fakat kolejden 11 yaşından önce öğrenci kabul edilmeyeceğine dair cevap alınması üzerine, babasının, Halide'nin yaşını büyüttürerek koleje yazdırması, Halide'nin 1 yıl okulda kalabilip, irade ile okuldan çıkarılması, 15 yaşında ise koleje ikinci defa başlaması ve 1901 yılında koleji bitirmesi (Adıvar, 1985: 5, 80, 81, 99), Amerikan kolejlerine karşı toplumdaki talebi ortaya koymaktadır.

Antep'teki Central Turkey College kampüsünün arsasının bir hacı ve bir Türk olan Antepli Kethüdazade Hacı Göğüş Efendi tarafından hibe edilmesi (Deringil, 2002: 139) ise üzerinde düşünülmesi gereken bir konudur.

\section{İngilizlerin Eğitim Faaliyetlerinin Denetimi}

Kamil Paşa, 1884 yılında Kıbrıs'ta, eğitimi rasyonalize etme görünümü altında, İngilizlerin bir kısım ilkokul öğretmenlerinin maaşlarında düzenlemeler yaptıklarını yazmaktaydı. Lefkoşa'nın Müslüman kesiminde de Protestan rahip tarafından idare edilen bir okul kurulmuştu (Deringil, 2002: 129, 130).

1893-1894 yıllarında ya da biraz daha sonra yazıldığı ihtimal dahilinde olan Maarif Nazırı Ahmet Zühdü Paşa'nın yabancı okullar hakkındaki raporuna göre ise Suriye kıt'asında Fransa ile beraber İngiltere'nin nüfuzu, her devletten fazlaydı. Burada Almanya mektep vesaire ile İngiliz ve Fransız politikasına üstün gelmek, en azından ona yetişmek için mücadele etmekteydi. Yine bölgede Rusya ile Amerika'nın da mücadele ettiği görülmekteydi (Çetin, 1983: 189, 191, 192, 201, 202).

II. Abdülhamit döneminde Suriye ve Beyrut gibi değerli iki Arap vilayetinde, İngiliz Anglikan misyonerler, Şii Dürzileri hedef kitle olarak belirlemişlerdi. Sağlık hizmeti sunmasıyla 
beraber, açılan okullarla seçtikleri topluluğun kalbini kazanmak istemekteydiler (Uyanık, 2014: $38)$.

1891 yılında Beyrut Vilayeti Kudüs-i Şerif Mutasarrıflı̆̆ı maiyetinde çalışan kaimakam mülazimlerinden Mihran Boyacıyan, II. Abdülhamit'e Beyrut Vilayeti'ndeki yabanc1 okullara dair bir rapor sunmuştu (Çetin, 1984: 316). Bu raporda, İngilizlerin çıkarları doğrultusunda özel önem verip, 30 sene önce komiser sıfatıyla Beyrut'a gönderdikleri ve şimdi de siyaset dünyasında şöhreti olan, çok daha önce İngiltere'nin İstanbul sefiri olan Lord Döfrin'in, Fransızların önüne, Dürzileri himaye ederek büyük bir set çektiği belirtilmişti. Ayrıca o zamandan beri Dürzilerin İngiltere'nin hususi himayesinde olup, İngiliz terbiye ve muhabbeti ile büyüdükleri ve Dürzilerin gerektiğinde, İngilizlerin istediği gibi istihdam edileceklerinin kararlaştırılmış olduğu ve bu toplumun bir süredir Cebel İngilizleri diye anıldıkları da bildirilmişti. Dürzilerden başka, yavaş yavaş İngiliz himayesine giren ve İngilizlerin hususi terbiyelerini görmekte olan, Cebel-i Lübnan ve Suriye'ce siyaseten özel önemleri olan Nusayri ve mütevellilerin de dikkatleri çekmekte olduğu ifade edilmekteydi. Rapora göre İngilizlerin eğitim hinterlandında 16 erkek öğretmen, 180 erkek öğrenci, 62 bayan öğretmen ve 1617 kız öğrencinin olduğu ve İngiltere'den eğitim için buraya 125.000 Frank yardım geldiği belirtilmekteydi (Çetin, 1984:319, 320, 322; YPRK MF 2/23).

Boyacıyan Beyrut'ta, Siro İngiliz Mektebi'nin, Suriye'deki İngiliz eğitim şubesinden olduğunu, İngiliz misyonerleri tarafından ücretsiz idare edildiğini ve çoğunluğu Dürzi ve Müslüman kızı içeren diğer 6 İngiliz mektebinin daha olduğunu ve hepsinin masrafinın İngiltere'den gelen yardımlarla ödendiğini ifade etmektedir (Çetin, 1984: 324).

Osmanlı topraklarındaki İngiliz mektepleri hakkında İngiltere Sefareti tarafindan takdim edilip, 22 Temmuz 1902 tarihli Sadaret tezkiresine ekli olan cetvelin içeriğine uygun olarak 2 Ağustos 1902 tarihinde belirtilen ve ruhsatsız başlığı altında ifade edilen ${ }^{4}$ Osmanlı topraklarındaki İngiliz okulları ise şunlardır:

\section{Suriye Vilayeti}

London Jews Society Cemiyeti tarafından Şam'da 1871'de kurulmuş olan mektep,

Church Missionary Society Cemiyeti tarafindan Selta'da kurulmuş olan mektep,

El Hüsn'de 1884'te 1'i erkek diğeri kızlara mahsus olarak kurulan 2 mektep,

Harire'de 1884'te kurulan erkek mektebi,

Salabağan'da Asuri Hıristiyanlarına mahsus olarak Kanterböri Piskoposu tarafından vücuda getirilen kuruma bağlı mektep.

\section{Aydın}

İzmir'de Ekol Komersiyal İngiliz namıla 1872'de kurulan mektep,

İzmir'de English High School namıla 1899'da kurulan mektep,

\footnotetext{
${ }^{4}$ Belgede geçen Cebel-i Lübnan'daki kurumlara burada yer verilmedi. Çünkü bu kurumlar ruhsatlı ya da ruhsatsız şeklinde ifade edilmemişti.
} 
İzmir'de Ekol de Miss Smitt namıla 1898'de kurulan mektep,

İzmir'de Misyon Dekeliz de Kosi Cemiyeti tarafindan 1858'de kurulan mektep,

Bornova'da Ekol de Buviye namıla 1895'te kurulan mektep,

Bornova'da Ekol de Miss Yilkins namiyla 1855'te kurulan mektep,

Buca'da İngiliz School namıyla 1894'te kurulan mektep.

\section{Kudüs-i Şerif}

Kudüs-i Şerif'te Anglikan Cemiyeti tarafından $1888^{\prime}$ de kız ve 1899 'da gündüzlü olarak kurulan erkek mektebi,

Kudüs-i Şerif'te London Jews Society Cemiyeti tarafindan 1839'da kurulan Sanayi Mektebi ve $1857^{\prime}$ de kurulan yatılı erkek mektebi,

Kudüs-i Şerif'te Church Missionary Society Cemiyeti tarafından 1876'da kurulan 1'i erkeklere diğeri kızlara mahsus 2 mektep,

Gazze'de 1868'de kurulan 1'i erkeklere ve diğeri kızlara mahsus 2 mektep,

Yafa'da 1865 'te kurulan 2 adet gündüzlü erkek ve 1890 'da kurulan gündüzlü sıbyan mektebi.

Remle'de 1860'ta kurulan 1'i erkeklere ve diğeri kızlara mahsus gündüzlü 2 mektep,

Leyde'de 1860’ta kurulan gündüzlü k1z mektebi,

Remle'de 1868 'de ve 1878 'de kurulan erkeklere mahsus gündüzlü 2 mektep,

Tayyibe'de 1878'de kurulan gündüzlü kız mektebi,

Enifa'da 1880'de kurulan gündüzlü erkek mektebi,

Biruzzeyd'de 1880'de kurulan 1'i erkeklere ve diğeri kızlara mahsus gündüzlü 2 mektep,

Ubud'da 1878'de kurulan gündüzlü erkek mektebi.

\section{Beyrut}

Beyrut'ta 1868'de kurulan Saint George Sanayi Mektebi,

Beyrut'ta $1865^{\prime}$ de kurulan erkek mektebi,

Beyrut'ta 1866 'de kurulan kız mektebi,

Safed'de Museviler arasında Hıristiyanlığın yayılması için Londonin Cemiyeti tarafından 1883 'te kurulan k1z mektebi,

Church Missionary Society Cemiyeti tarafindan Nablus'ta 1856 'da ve Rafekiye'de 1860 'da ve Zebabe'de 1874 'te kurulan 2'şer adet erkek ve kızlara mahsus mektepler ve keza Church Missionary Society Cemiyeti tarafindan Nasbin'de 1874'te, Burkai'de1884'te ve Gaburi'de 1884'te kurulan 1'er adet erkek mektebi.

\section{Halep}


İntakiye'de Presbiteryen mezhebinin İskoçya ve İrlanda Protestanları şubesine mensup olarak 1876'da kurulan mektep (YPRK MF 4/55).

Osmanlı mülkündeki İngiliz okullarından 48'inin ruhsatsız başlığı altında verilip, faaliyet gösterdiği görülmektedir. Ruhsatlı olanlar arasında ise Bağdat'ta İngiliz Protestan Mektebi adıyla bilinen ve 1896'da kurulup aynı yıl 19 Nisan'da ruhsata bağlanmış olan mektep ile beraber Selanik'te 1857 'de kurulup 2 Eylül 1892 'de ruhsata bağlanan İskoçya Kilisesi misyonerleri tarafindan kurulan kız mektebi ile yine Selanik'te Miss Donlanson adıyla 1888'de kurulup 1892 'de ruhsata bağlanan mektep ve İzmir'de School Evangelik adıyla 1739'da kurulup, 1839'da ruhsata bağlanan okul dikkatleri çekmektedir (YPRK MF 4/55).

Görüldüğü üzere, okullar kurulduğu yıl veya kurulduktan yıllar sonra ruhsat alabilmektedir.

Ruhsat almış okullar, önceden, yıllarca ruhsatsız çalışabilmekte, ruhsat almayanlar da bu çalışmalarına devam edebilmektedirler. Hal böyleyken İngiliz okullarının denetimi nasıl mümkün olmaktadır?

İşte bu konuda, yukarıda belirttiğimiz cetvelde ruhsatı da bulunan, Bağdat Protestan Mektebi'nin teftişi ile ilgili durum, konunun aydınlatılması konusunda yol gösterici olacaktır.

Şöyle ki, Bağdat Maarif İdaresi 25 Haziran 1904'te Vilayet İdare Meclisi'ne havale edilmesi için, vilayete şu durumu bildirmiştir:

Maarif Nezareti'nin isteği üzerine İngiltere Devleti tebaasından mektep mesul müdürü Protestan rahiplerinden Mister Parfesin adına 5 Aralık $1896^{5}$ tarihiyle resmi bir ruhsatname verilmişti. $\mathrm{Bu}$ ruhsatnamede öğretimine ruhsat verilen kitaplar haricinde diğer bir kitap okutmamak ve kitaplardan birisi veya birkaçı değiştirilecek olursa Maarif Meclisi'nden onay alınmadıkça okutturulmamak, mektebin bir yerden diğer bir yere nakline ihtiyaç görülürse, maarif müdüriyetine bilgi verilip, Maarif Nezareti'nden izin çıkmadıkça nakil edememek ve öğrencilerin imtihanları sırasında ve ödül dağıtma törenlerinde maarif ya da hükümet memurlarından birisi hazır bulunmak ve her sene bu mektepten diploma alarak çıkacak talebenin isimlerini belirten defteri verilmek ve senede bir defa olarak öğrencilerin devam cetveli verilmek şartları vurgulanmaktaydı. Ayrıca maarif müfettişleri mektebe geldiklerinde gerekli kolaylığı göstermek, ruhsatnamede yazılı Maarif-i Umumiye Nizamnamesi’nin 129. maddesi hükümlerine müdür, kurucular ve öğretmenler harfiyen uymak, mektep yerli ve yabancı İngiliz Protestan çocuklarına mahsus olup, eskiden olduğu gibi alışılmış binalardan sayılmak, günlerden bir gün kesinlik kazanmamak ve diğer milletlerden öğrenci kayıt ve kabul etmemek, erkek ve kız karışık bir yerde toplamamak, nizamnamenin hükümlerine uygun hareket etmek şartlarının sağlanması da istenmekteydi. Gerektiğinde mektebe gidilerek ruhsatnamedeki şartların tamamıyla yerine getirilip getirilmediği, ara sıra tetkik ve teftiş

\footnotetext{
${ }^{5}$ Osmanlı topraklarındaki İngiliz mekteplerini belirten ve İngiltere Sefareti tarafından Osmanlı yönetimine verilen evrakta okulun ruhsat tarihi 19 Nisan 1896 olarak geçmektedir (Y PRK MF 4/55). 28 Nisan 1896 tarihli Hariciye Nezareti'nin İngiltere Sefareti'ne yazdığı evrakta da okulun açılışı için ruhsatı kapsayan padişah iradesi mucibince Maarif-i Umumiye Nizamnamesi'nin 129. maddesi hükümlerine uyulmasının yeterli olduğu belirtilmekteydi (BEO 2493/186912). O zaman okul 19 Nisan 1896'da ruhsata bağlanmış (Y PRK MF 4/55), 5 Aralık 1896'da da okulun mesul müdürü Mister Parfesin adına ruhsatname de, bazı başka şartların da ilave edilmesiyle verilmiştir (BEO 2493/186912).
} 
edilmekteydi. Bu defa vilayet merkezinde bulunan bütün ecnebi ve gayrimüslim okullarının teftişi sırasında, mektebe gidildiği halde mektep memurlarından meçhul bir şahıs, içeriye girilmesine engel olarak, mektep müdürlügünden kendisine verilen emirde mektebe girilmesi ve teftişi için mutlaka Bağdat İngiltere Konsolosluğu'na durumun bildirilmesi ve konsolosluk ruhsat vermedikçe mektebe girişe izin verilmemesi gereğinin belirtildiğini ifade etmiştir. Halbuki mektebin mesul müdürü adına verilen ruhsatnamede bulunan şartlarda bu gibi bir koşul bulunmadığından, bu konudaki muameleler nizama aykırıdır. Ayrıca edinilen bilgiye göre mektebin mesul müdürü Mister Parfesin azledilmiş ve Londra'ya gitmiş, yerine tayin edilen kişi idareye müracaat etmemiş ve mektep öğretmenlerinden bazıları da değiştirilmiştir. Bu öğretmenler de idareye bilgi vermemişlerdir. Velhasıl mektebin idaresi, verilen ruhsatnamedeki şartlara aykırı durumdadır. Maarif-i Umumiye Nizamnamesi'nin 129. maddesine uygun olarak mektebin kapatılması, müdürün maarif idaresine başvurarak ruhsatnamedeki şartlar ve Maarif-i Umumiye Nizamnamesi'nin 129. maddesinde yazılı hükümlere tamamen mecbur tutulması sebeplerinin karara bağlanması için durumun Vilayet İdare Meclisi'ne havalesi gereklidir (BEO 2493/186912).

Konu Mekatib-i Gayr-i Müslime ve Ecnebiye Müfettişliği’ne havale edilmiş ve Bağdat Protestan Mektebi'nin müdürüyle öğretmenlerinden bazılarının değiştirilmesinde, Maarif-i Umumiye Nizamnamesi'nin 129. maddesine ve ruhsatnamedeki şartlara uygun olarak Bağdat Maarif İdaresi'ne müracaatla, usulünce gereken muamelelerin yapılması ve teftiş için mektebe gidecek maarif memurlarına kolaylık gösterilmesi gerektiği halde, mektep idaresi tarafından buna uyulmaması caiz olmamakla beraber, bu mektebin esasen resmi ruhsat1 olması sebebiyle, mevcudiyetlerinin tasdiki padişah iznine bağlı İngiliz mektepleri arasında bulunmadığının bu konuda daha önce Sadaret'ten verilen cetvelin tetkikinden anlaşılmış olduğu belirtilmiştir. Şu halde nizamname ve ruhsatname hükümlerinin uygulanması gereğinin mahalline cevap olarak tebliği gerekirse de asıl mesul müdürün İngiltere Devleti tebaasından Mister Parfesin olmasına nazaran bu tebliğden önce, bu konuda İngiltere Devleti Sefareti'ne tebligat yapılması gerekmektedir. Müfettişliğin bu tespitleri 13 Ağustos 1904'te Maarif-i Umumiye Nazırı imzasıyla kaleme alınmıştır (BEO 2493/186912).

1 Aralı 1904'te İngiltere Sefareti'nden Hariciye Nezareti'ne gelen evrakın tercümesinde ise İngiltere, konu hakkında bir savunma yapmıştır.

Şöyle ki, sefaret, Hariciye Nezareti'nin 28 Nisan 1896 tarihli evrakıyla kendisine bildirildiği üzere, mektebin açılışına, ruhsatı içeren padişah iradesi gereğince Maarif-i Umumiye Nizamnamesi'nin 129. maddesi hükümlerine uyulması yeterli iken, maarif müdüriyetinin bu madde hükümlerine temas etmeyen bazı sebeplerden dolayı, önceden konsolosa bilgi vermeksizin, mektebe zorla girmek istemiş olduğu haber alınmış olduğundan, mektep müdüriyeti hareketinden dolayı azarlanamaz (BEO 2493/186912).

26 Ocak 1905'te Sadaret'ten Maarif Nezareti'ne yazılan evrak, konu hakkında son noktayı koymuştur. Şöyle ki, sefaretten alınan yukarıdaki cevabi beyanla beraber, Bağdat İngiltere Konsolosluğu'na bu konuda uygun hareket etmesi şeklinde tavsiye ve tembih edilmiştir (BEO 2493/186912). 
Anlaşıldığı üzere, Bağdat maarif idaresi, İngiliz Protestan Mektebi'nin, Mister Parfesin adına verilen ruhsatnamesinde yazan şartlara göre okulun zaman zaman teftiş edildiğini ama bu sefer öğretmen ve okul müdürünün değiştiğini; teftiş için okula girilmesine izin verilmeyerek, Bağdat İngiltere Konsolosluğu'ndan izin alınmadıkça okula girilmesine izin verilmeyeceğinin belirtildiğini ifade etmektedir. Okulun ruhsatında, Bağdat İngiltere Konsolosluğu'ndan izin almak gibi bir şart olmadığından, okul kapatılmalı ve müdür de Maarif-i Umumiye Nizamnamesi'nin 129. maddesi hükümleriyle ruhsatnamedeki şartlara uymaya mecbur tutulmalıdır.

Mekatib-i Gayr-i Müslime ve Ecnebiye Müfettişliği ise okul idaresinin davranışının uygun olmadığını, ayrıca da mektebin ruhsatının olduğunu fakat okulun varlıklarının onayı padişah iznine bağlı İngiliz okulları arasında bulunmadığını ortaya koymuştur. Şu halde ruhsatname ve nizamname hükümlerine göre hareket edilmesinin Bağdat Maarif Müdürlügü’ne bildirilmesi fakat okul müdürü İngiliz vatandaşı olduğundan, durumun öncelikle İngiliz Sefareti'ne tebliği gereklidir.

İngiltere Sefareti ise Maarif-i Umumiye Nizamnamesi'nin 129. maddesi hükümlerinin yeterli olduğunu, çünkü Hariciye Nezareti'nin 28 Nisan 1896 tarihli evrakında böyle ifade edildiğini, konsolosa bilgi verilmeden mektebe girilmeye çalışıldığını ve mektep müdürünün de azarlanamayacağını belirtmiştir. Burada İngiliz Sefareti'nin, mektebe giriş için konsolosa önceden bilgi verilmesi gerektiğini belirtmesi, Osmanlı eğitim siyasasının yabancı devlet ve okullar karşısındaki hükümlerinin ne kadar geçer akçe olduğunu göstermektedir. Zaten Sadaret makamı da konu hakkında İngiltere Konsolosluğu'na uygun hareket etmesi konusunda tavsiye ve tembihte bulunulduğunu ifade etmiştir ki, Mekatib-i Gayr-i Müslime ve Ecnebiye Müfettişliği Nizamnamesi'nin 5. maddesi “velhasll teftişin her cihetine irae-i muvafakat ve teshilat olunup, ecnebilerin mensup olduklart sefaretlere istinaden veyahut keyfiyet-i teftiş anlardan alacakları mezuniyete ta'liken (bağlı olarak) hiçbir mümanaat (engel) gösterilmeyecektir” (Y PRK MF 1/63), demektedir. Yani teftişe kolaylık gösterilecek, sefaretler aracılığıyla teftiş engellenmeye çalışılmayacaktır.

\section{Denetim Çabası ve Rekabet}

Mihran Boyaciyan'ın 27 Eylül 1891 tarihli II. Abdülhamit'e sunulmuş Beyrut Vilayeti'ndeki yabanc1 okullara dair raporda, yabanc1 okulların eğitim adı altında Osmanlı Devleti aleyhindeki zararları ve devlete çıkardıkları güçlükler de ortaya konmuş, çözüm olarak devletin daha bilinçli davranması gereği, Türkçeye önem verilmesi, eğitim ödeneğinin artırılması, Beyrut Vilayeti'nin öne çıkan kazalarında derhal birer Osmanlı mektebinin açılması, iyi öğretmenlerin atanması, Türkçeye aşina olmayanların memuriyete alınmaması ve tüm yazışmaların Türkçe yapılması gibi öneriler sunulmuştur (Çetin, 1984: 316, 317).

Maarif Nazırı Ahmet Zühdü Paşa'nın Osmanlı İmparatorluğu'ndaki yabancı okullar hakkındaki 1893 ya da 1894 yılında veya biraz daha sonra yazıldığı ihtimal dahilinde olan raporunda ise, yabancıların zararlı hareketlerine engel olmak için gayrimüslim Osmanlı tebaasının yaşadığı köy ve kasabalardaki okullarda yabancı öğretmenlere yer verilmemesi, yabancıların okul açacakları yerlerde ecnebi tebaasından çocuk yoksa okulun kuruluşuna ruhsat verilmemesi, verildiği zaman da gereken teftişlerin yapılması, Osmanlı tebaasının bu mekteplere 
kesinlikle gönderilmemesi, gayrimüslim tebaanın okullarında Osmanlıcanın zorunlu olması, teftişin sıklıkla yapılması, yabancı ülkelerdeki gibi eğitimin yıllık bütçesinin arttırılması belirtilmekteydi. Hatta Surbistan, Romanya, Bulgaristan gibi küçük devletlerin eğitim bütçesine ayırdıkları rakamlar örnek olarak sunulmakta, bu türlü önlemlerin alınması da ifade edilmekteydi (Çetin, 1983: 192, 193).

İstanbul Alman Mektebi müdürlüğünü ve muallimliğini yapmış Dr. Richard Preuser'in yabanc1 okulları dolayısı ile Protestan okullarını da kapsayan ifadelerine bakıldığında, ecnebi mekteplerinde Türkçe öğretimin elim bir durumda olduğu, hayret verici bir durum olarak çocuklarını bu derslere sokmayanların bizzat Türkler olduğu, Coğrafya dersinde Türkiye'nin değil, ilgili devletlerin coğrafyasının öğretildiği, bu okullarda çocuklara dini telkin ve tesirlerde bulunulduğu, bu okulların bazılarında Türk çocuklarının Hıristiyan ibadet, dua ve dini törenlerine dahil edildikleri görülmektedir. Hatta bazı durumlarda özür dileme şeklinde haçın bile bu çocuklara öptürüldüğ̈̈, asıl garip olanın ise velilerin bu durumları bilip de itiraz etmemelerinin olduğu da ortaya konmaktadır (Preuser'den aktaran Akyüz, 1970: 126).

1893 tarihli Maarif Nazırı Zühdü Paşa'nın tezkeresine bakıldığında, Osmanlı topraklarındaki 392 adet Protestan ve Amerikan okulundan 341 tanesinin hükümet memurlarının müsamahasından faydalanılarak vaktiyle ruhsatsız olarak açıldıkları görülmektedir (Akyüz, 1970: 121-123).

Zühdü Paşa, Protestan okullarının denetimi konusunda da, teftiş diye bir kurum olmadığından, ecnebilerin tam bir firsat bularak hükümet memurları ve maarif müfettişleri okulun bir tanesine gitmek isterlerse okula kabul edilmediklerini; ayrıca onların, müdür, kurucu ve öğretmenlerin tabi oldukları konsoloshanelere ve oradan da sefaretlere yönlendirildiklerini ifade etmekte ve teftişe izin verilmeyerek bir cevap vermekten de kaçınıldığının her gün rastlanan olaylardan olduğu belirtilmektedir. Bununla beraber Zühdü Paşa, Maarif Nezareti'nin bu okulların hukuki statüsünü normalleştirmek için bu mekteplere ruhsat verme yolundaki teşebbüslerine de ilgili devletlerin elçileri tarafından engel olunduğunu eklemektedir (Akyüz, 1970: 126).

II. Abdülhamit ise Protestan okullarına ve öbür yabanc1 mekteplere Müslüman çocuklarının gitmesini istememektedir (İ DH 1066/83576).

Anadolu Umum Islahat Müfettişi Şakir Paşa, teftiş ettiği 9 Anadolu vilayetindeki yabancı okullar hakkında yazdığı layihada, Protestan okulları ve diğer yabancı okulların zararlarına ve azınlıkların Anadolu ticaret ve sanayiini tam olarak ellerine geçirmeleri tehlikesine karşı bu okulların kapatılması ya da s1kı bir denetime tabi tutulmalarını önermekte, yabancı okulların komple kapatılmasının büyük siyasi sorunlar ortaya çıkaracağı şüphesiz olduğundan, bu sebeple ikinci yolun uygulanmasının gerekliliğini ifade etmektedir (Akyüz, 1970: 126-128). Koçer (1991: 115), ise yabancı okullarında devlet kontrolünün söz konusu olmadığını belirtmektedir.

Osmanlı toprakları misyonerlerin kendi aralarındaki mezhep mücadelelerine de sahne olmaktaydı. Protestan misyonlarında Katoliklik karşıtlı̆̆ görülmekteydi. Robert Kolej'in kurucusu Hamlin, bu rekabeti güçlü olanın varlığını sürdürebileceği bir mücadele olarak görüyor ve Cizvit mekteplerini de Roma'dan gelen tehdit olarak nitelendiriyordu (Deringil, 
2002: 136). Cebel-i Lübnan'da ise Fransızların eğitim politikasına karşı öncelikle İngiltere'nin rekabeti ön plana çıkmaktaydı (Çetin, 1984: 317).

1884 y1lında İngiliz Sefareti, Halep'te kurulmak istenilen Protestan okulunun yerel idareciler tarafindan engellendiğinden şikayet etmekteydi. İngiliz konsolos, Katolik okul ve kiliselerine kesinlikle karışılmadığından, durumun tatsızlığını ifade etmişti. Bu, yabancı okullara eşit muameleyi içeren Osmanlı güvencesiyle bağdaşmamaktaydı.

Amerikan Orta Elçiliği, okullar konusunda yeni ruhsatlar alabilmek için, Osmanlı Hükümeti üzerinde baskı kurmaktaydı. Orta elçilik, Amerikan kurumlarının, Fransız okullarına verilen vergi ödememe gibi ayrıcalıklardan faydalanmasını isteyerek, baskısını devam ettirmekteydi. $\mathrm{Bu}$ durum, Osmanlı Devleti için Protestan kurumlarının adet ve nüfuzunun artması tehlikesini doğurabilirdi. 1906 yılında hükümet, Amerikan misyoner kuruluşlarına Müslüman çocuklarının alınmayacağının kabul edilmesi halinde ruhsat verileceğini Amerikan Orta Elçiliği'ne bildirdi. ABD temsilcisi, Amerikan Hükümeti'nin, vatandaşlarına, Fransızlara, Ruslara veya İngilizlere davranıldığı gibi davranılması görüşünde olduğunu belirtti. Ayrıca Fransa, Rusya ve İngiltere gibi Amerika'nın da milyonlarca Müslüman uyruğunun olduğu, Osmanlı Hükümeti'ne ifade edildi. Hariciye Nazırı Tevfik Paşa, Amerika'nın büyük bir devlet haline geldiğinden, görüşlerini kabul ettirmek için Osmanlı Hükümeti'ni zorladığını belirtecekti (Deringil, 2002: 130, 137).

10 Ocak 1907 tarihinde Sadaret'ten Maarif Nezareti'ne yazılan evrakta ise İzmir'de Amerikan Board adlı misyoner cemiyeti kurumlarından olan, erkeklere ayrılmış kolej binaları ile bir kiliseyi de içine alan, kızlara ayrılmış okulun mülk ve vakıf arsalarının Amerikan Board Cemiyeti adına tashih-i kaydı ve masrafsız olarak tapu senetlerinin verilmesi, vergi ve çeşitlerinden müstesna tutulmaları iltiması için Amerika Sefareti'nin resmi yazı ile istekte bulunduğu belirtilmekteydi (BEO 2978/223307). Konu, Divan-1 Hümayun, Hariciye Nezareti, Şura-yı Devlet Mülkiye Dairesi, Meclis-i Mahsus-1 Vükela, Sadaret ve Maarif Nezareti'nin malumuydu (BEO 2978/223307).

Neredeyse devletin ilgili tüm kurumlarında görüşülen durum, sanki Hariciye Nazırı Tevfik Paşa'yı haklı çıkarmaktaydı.

Amerikan Board'ın sunduğu eğitim imkânları genel olarak Osmanlı Devleti'ninkinden daha iyi idi (Deringil, 2002: 135).

Devlet, misyoner okullarıyla aynı şekilde rekabet etmeli ve Müslüman okullarının kalitesini arttırmalıydı. 1905'te Beyrut Vilayeti, Cizvit ve Protestanların zararlarından Müslüman çocukların kurtarılması için onlarla rekabet edebilecek güçte modern mekteplerin kurulmas1 gereğini belirtmekteydi. Süleyman Hüsnü Paşa, Müslüman misyoner derneğinin kurulmasını savunmakta; Hoca Tahsin Efendi, Müslüman Ülkelerin Coğrafyasını Araştırma Derneği'ni oluşturmaktaydı. II. Abdülhamit döneminin valileri de, üst düzey eğitime karş1 rekabetin tek çaresinin, onun bir dengini oluşturmak olduğunu çok iyi bilmekteydiler (Deringil, 2002: 137, 138). Anlaşıldığı üzere, Osmanlı topraklarında eğitim alanındaki rekabet, hem misyonerlerin kendi aralarındakini hem de Osmanlı Devleti ile misyonerler arasındaki rekabeti kapsamaktaydi. 


\section{Sonuç}

Tebaasının aidiyet duygusunu güçlendirmede eğitimin öneminin farkında olan Osmanlı Devleti, çocuklarının yabancı okullara gitmelerini istememektedir. Müslüman çocuklarının yabancı okullara gitmemeleri için onlarla rekabet edebilecek modern okullara ihtiyaç vardır. Devlet, Müslüman okullarını ilkokullardan başlayarak geliştirmeye, hatta yabancı mekteplerden daha iyi hale getirmeye çalışmaktadır. Padişah, Müslüman çocuklarının yabancı okullara ve Protestan mekteplerine gitmelerinin engellenmesini istemektedir.

Yabancı ve Protestan okullarının denetimi de hem kanunen gerekli, hem de verilen eğitimin devlet ideolojisi ile bağıntısını anlamak açısından önemlidir. Hukuki düzenlemeler yabanc1 okulları ve Protestan okullarını denetlemek için yeterli olmakla beraber, uygulamada sorunlar yaşanmaktadır. Teftiş konusunda kanun ve uygulama arasındaki uyumsuzluk, Osmanlı vilayetlerindeki yöneticilerin sıklıkla merkezi yönetime başvurmalarına neden olmaktadır. Teftiş için Osmanlı hükümetiyle sefaretler arasındaki diyalogun sonlanması da beklenmektedir.

Osmanlı Devleti, Müslüman okullarının kalitesini artırarak, padişah emriyle ve denetim mücadelesiyle, Müslüman çocuklarının yabancı okullara gidişinin önünü kesmeye çalışmaktadır.

Toplumsal anlamda, Protestan okullarının talep görmesinde, eğitim imkânlarının iyi olması, öne çıkan neden olarak düşünülebilir. Devlet, iyi eğitime karşı iyi eğitimle rekabet etme niyetindedir. Tüm yapılanlara rağmen, yabancı okullar ve Protestan okulları, Osmanlı toplumunun ilgisini çekmeye devam etmektedir.

Büyük devletlerin, Osmanlı topraklarındaki kendi okulları konusundaki, kendi aralarındaki rekabet, Osmanlı Devleti'ne, ayrıcalık alma yarışı sonundaki dış baskı olarak yansımaktadır. Sefaret ve konsolosluklar, güçlerini kullanarak, okullarının denetimini engellemeye çalışmaktadır. Devlet denetiminin ulaşmada zorlandığı bu okulların, sefaretlerinin desteğiyle de facto özerk bir yapıdaymış gibi hareket etmeleri, bulundukları bölgelerde oluşturdukları nüfuz alanları ve hangi bölgelerde açıldıkları düşünüldügünde, yıllar sonra, Osmanlı Devleti ile imzalanacak antlaşmaların hiç de birdenbire kaleme alınmadığını ortaya koyacaktır.

Sonuç itibariyle, Osmanlı bürokrasisinin, Protestan okullarını ve yabancı okulları denetlemeye, teftişe niyetli fakat yeterince muktedir olmadığı ortaya çıkmaktadır.

\section{KAYNAKÇA}

Türkiye Cumhuriyeti Cumhurbaşkanlığı Devlet Arşivleri Başkanlığı

\section{Devlet Arşivleri Başkanlığı Osmanlı Arşivi}

Bab-ı Ali Evrak Odası (BEO), Dosya No: 159, Gömlek No: 11885.

Bab-ı Ali Evrak Odası (BEO), Dosya No: 177, Gömlek No: 13272.

Bab-ı Ali Evrak Odası (BEO), Dosya No: 2493, Gömlek No: 186912.

Bab-ı Ali Evrak Odası (BEO), Dosya No: 2628, Gömlek No: 197046. 
DİYALEKTOLOG

ULUSAL SOSYAL BİLİMLER DERGİSI

BAHAR SPRING 2020-SAYI/ ISSUE 23-SAYFA PAGE 1-29

Bab-ı Ali Evrak Odası (BEO), Dosya No: 2978, Gömlek No: 223307.

Dahiliye Muamelat (DH TMIK M), Dosya No: 132, Gömlek No: 52.

Dahiliye Nezareti Mektubi Kalemi Tasnifi (DH MKT), Dosya No:1405, Gömlek No:29.

Dahiliye Nezareti Mektubi Kalemi Tasnifi (DH MKT), Dosya No:1979, Gömlek No:56.

Dahiliye Nezareti Mektubi Kalemi Tasnifi (DH MKT), Dosya No:2605, Gömlek No: 87.

Irade Dahiliye Tasnifi (İ DH), Dosya No: 1066, Gömlek No: 83576.

Maarif Nezareti Mektubi Kalemi Evrakı (MF MKT), Dosya No: 6, Gömlek No: 114.

Maarif Nezareti Mektubi Kalemi Evrakı (MF MKT), Dosya No: 74, Gömlek No: 50.

Maarif Nezareti Mektubi Kalemi Evrakı (MF MKT), Dosya No: 94, Gömlek No: 46.

Maarif Nezareti Mektubi Kalemi Evrakı (MF MKT), Dosya No: 94, Gömlek No: 103.

Maarif Nezareti Mektubi Kalemi Evrakı (MF MKT), Dosya No: 172, Gömlek No: 2.

Maarif Nezareti Mektubi Kalemi Evrakı (MF MKT), Dosya No: 192, Gömlek No: 99.

Maarif Nezareti Mektubi Kalemi Evrakı (MF MKT), Dosya No: 239, Gömlek No: 32.

Maarif Nezareti Mektubi Kalemi Evrakı (MF MKT), Dosya No: 294, Gömlek No: 13.

Maarif Nezareti Mektubi Kalemi Evrakı (MF MKT), Dosya No: 309, Gömlek No: 6.

Maarif Nezareti Mektubi Kalemi Evrakı (MF MKT), Dosya No: 477, Gömlek No: 49.

Sadaret Mektubi Mühimme Kalemi Evrakı (A\}MKT MHM), Dosya No:724, Gömlek No:4.

Yıldız Esas Evrakı (YEE), Dosya No: 112, Gömlek No: 6.

Yıldız Perakende Evrakı Maarif Nezareti Maruzatı (Y PRK MF), Dosya No: 1, Gömlek No: 63.

Yıldız Perakende Evrakı Maarif Nezareti Maruzatı (Y PRK MF), Dosya No: 2, Gömlek No: 23.

Yıldız Perakende Evrakı Maarif Nezareti Maruzatı (Y PRK MF), Dosya No: 4, Gömlek No: 55.

\section{Kitap ve Makaleler}

Adıvar, H. E. (1985). Mor Salkımlı Ev, İstanbul, Atlas Kitabevi.

Alan, G. (2019). “Amerikan Board Örgütü’nün Ortadoğu Bölgesindeki Teşkilatlanmasında Asur Misyonu'nun Önemi (1851-1860)", Sosyal Bilimler Araştırmaları Dergisi, 14 (1), 17-49. Erişim adresi: http://dergipark.org.tr/tr/pub/gopsbad/issue/46703/521962

Aydın, M. (2008). Bulgarlar ve Ermeniler Arasında Amerikan Misyonerleri, 1. Baskı, İstanbul, Yeditepe Yayınevi.

Aydın, M. (2019). "Osmanlı Makedonyasında Slavist Bulgar Komita Faaliyetleri”, Belgi Dergisi, 2 (18),1587-1606. DOI: 10.33431/Belgi.575310

Akyüz, Y. (1970). "Abdülhamid Devrinde Protestan Okulları ile İlgili Orijinal İki Belge”, Ankara Üniversitesi Ë̆itim Fakültesi Dergisi, 3(1-4), 121-130. 
Akyüz, Y. (2001). Başlangıçtan 2001'e Türk Eğitim Tarihi, Sekizinci Bask1, İstanbul, Alfa Yayınlar1.

Çetin, A. (1983). “Maarif Nazırı Ahmed Zühdü Paşa'nın Osmanlı İmparatorluğu'ndaki Yabancı Okullar Hakkındaki Raporu”, Güney Doğu Avrupa Araştırmaları Dergisi,(10-11),189219.

Çetin, A. (1984). “II. Abdülhamid'e Sunulmuş Beyrut Vilayetindeki Yabancı Okullara Dair Bir Rapor”, Türk Kültürü,(253), 316-324.

Deringil, S. (2002). Iktidarın Sembolleri ve İdeoloji II. Abdülhamid Dönemi (1876-1909), Çeviren: Gül Çağalı Güven, İstanbul, Yapı Kredi Yayınları.

Kili, S. ve Gözübüyük, A. Ş. (2000). Türk Anayasa Metinleri, İkinci Basım, İstanbul, Türkiye İş Bankası Yayınları.

Koçer, H. A. (1991). Türkiye'de Modern Eğitimin Doğuşu ve Gelişimi (1773-1923),İstanbul, Milli Eğitim Bakanlığ 1 Yayınları.

Kodaman, B. (1999). Abdülhamid Devri Eğitim Sistemi, Üçüncü Baskı, Ankara, Türk Tarih Kurumu Basımevi.

Mahmud Cevad İbnü'ş-Şeyh Nafi (2002). Maarif-i Umumiye Nezareti Tarihçe-i Teşkilat ve Ícraatı, Yayına Hazırlayanlar: Mustafa Ergün, Tayyip Duman, Sebahattin Arıbaş, H. Hüseyin Dilaver, Ankara, Milli Eğitim Bakanlı̆̆ 1 Yayınları.

Tozlu, N. (1991). Kültür ve Eğitim Tarihimizde Yabancı Okullar, Ankara, Akçağ Yayınları.

Uyanık, E. (2014). "II. Abdülhamit ile Amerikan Protestan Misyonerlerinin Eğitim Mücadelesi: Amerika'ya Kaçırılan Nusayri Kızları”, Kebikeç Insan Bilimleri Iç̧in Kaynak Araştırmaları Dergisi (37), 35-56.

Uyanık, E. (2017). "Yabancı Okullarda Eğitim Gören Osmanlı'nın Müslüman Çocukları (18651908)”, Diyalektolog Ulusal Sosyal Bilimler Dergisi,(14), 1-29. DOI: http://dx.doi.org/10.22464/diyalektolog.133

Vahapoğlu, M. H. (2005). Osmanlı'dan Günümüze Azınlık ve Yabancı Okullar, İstanbul, Milli Eğitim Bakanlığı Yayınları.

Yıldız, Ö. (2009). Misyonerlik ve Amerikan Board Teşkilatı, İstanbul, IQ Kültür Sanat Yayınc1lı. 